\title{
EFFECTS OF IRRADIATION TEMPERATURE ON CHARPY \\ AND TENSILE PROPERTIES OF HIGH-COPPER, \\ LOW UPPER-SHELF, SUBMERGED-ARC WELDS*
}

\author{
Randy K. Nanstad and Reynold G. Berggren
}

\author{
Metals and Ceramics Division \\ OAK RIDGE NATIONAL LABORATORY
}

P.O. BOX 2008

Oak Ridge, TN 37831-6151

* Research sponsored by the office of Nuclear Regulatory Research, U.S. Nuclear Regulatory Commission, under Interagency Agreement DOE 1886-8109-8L with the U.S. Department of Energy under contract DE-AC05-840R2i400 with Martin Marietta Energy Systems, Inc.

\begin{abstract}
The submitted manuscript has been authored by a contractor of the U.S. Government under contract No. DE.AC05-84OR21400.

Accordingly, the U.S. Government retains \& nonexclusive, royalty-Iree license to publish or reproduce the published form of this

contribution, or allow others to do so, for U.S.

Government purposes.
\end{abstract}

\section{DISCLAIMER}

This report was prepared as an account of work sponsored by an agency of the United States Government. Neither the United States Government nor any agency thereof, nor any of their employees, makes any warranty, express or implied, or assumes any legal liability or responsibility for the accuracy, completeness, or usefulness of any information, apparatus, product, or process disclosed, or represents that its use would not infringe privately owned rights. Reference herein to any specific commercial product, process, or service by trade name, trademark, manufacturer, or otherwise does not necessarily constitute or imply its endorsement, recommendation, or favoring by the United States Government or any agency thereof. The views and opinions of authors expressed herein do not necessarily state or reflect those of the United States Government or any agency thereof. 
Randy K. Nanstad' and Reynold G. Berggren ${ }^{2}$

EFFECTS OF IRRADIATION TEMPERATURE ON CHARPY AND TENSILE PROPERTIES OF BIGB-COPPER, LOW UPPER-SHELF, SUBMERGED-ARC WELDS

REFERENCE: Nanstad, R. K., and Berggren, R. G., "Effects of Irradiation Temperature on Charpy and Tensile Properties of Bigh-Copper, Low Upper-Shelf, Submerged-Arc Welds," Effects of Radiation on Materials: 16th. International Symposium, ASTM STP 1175, Arvind S. Kumar, David S. Gelles, Randy K. Nanstad, and Edward A. Little, Editorg, American Society for Testing and Materials, Philadelphia, 1993.

ABSTRACT: The Heavy-Section steel Irradiation Program conducted the Second and Third Irradiation Series to investigate the effects of irradiation on the ductile fracture toughness of seven commercially fabricated low upper-shelf welds. All seven submerged-arc welds were fabricated with copper-coated wire and Iinde 80 flux and have average bulk copper contents ranging from 0.21 to 0.428 with nickel levels of about 0.68 . The preirradiation upper-shelf energies range from 74 to $111 \mathrm{~J}(55-82 \mathrm{ft}-1 \mathrm{~b})$. Compact specimens up to $101.6 \mathrm{~mm}$ (4 in.) thick, $4 \mathrm{TC}(\mathrm{T})$, were irradiated at nominally $288^{\circ} \mathrm{C}$ in the Bulk shielding Reactor at Oak Ridge National Laboratory to fluences ranging from about 4 to $12 \times 10^{18}$ neutrons $/ \mathrm{cm}^{2}(>1 \mathrm{MeV})$. Charpy $\mathrm{V}$-notch and tensile specimens were included in the capsules at available locations which were subject to wide variations in irradiation temperature and fluence.

This paper presents analyses of the charpy impact and tensile test data, including adjustments for irradiation temperature and fluence normalization which make possible comparison of the irradiation sensitivity of the different welds. Analyses revealed a dependence of yield and ultimate strength on irradiation temperature of -1.1 and $-0.8 \mathrm{MPa} /{ }^{\circ} \mathrm{C}$, respectively. Similarly, the Charpy impact energy changes due to irradiation temperature were $-0.5^{\circ} \mathrm{C} /{ }^{\circ} \mathrm{C}$ for transition temperature shift and $-0.05 \mathrm{~J} /{ }^{\circ} \mathrm{C}$ for the upper-shelf energy decrease. After adjustment to an irradiation temperature of $288^{\circ} \mathrm{C}$ and normalization to a fluence of $8 \times 10^{18}$ neutrons $/ \mathrm{cm}^{2}$, percentage increases in yield strength due to irradiation ranged from about 21 to 358 while those for ultimate strength ranged from about 13 to 208 . The charpy transition temperature shifts ranged from 59 to $123^{\circ} \mathrm{C}$ while the postirradiation upper-shelf energies ranged from 58 to $79 \mathrm{~J}$.

KEYWORDS: Charpy V-notch impact, copper content, fracture toughness, irradiation, irradiation temperature, light-water reactors, Linde 80 flux, neutron fluence, reactor pressure vessels, submerged-arc welds, surveillance, tensile strength, transition temperature shift, upper-sheif energy drop, yield strength

'Leader of Fracture Mechanics Group, Metals and Ceramics Division, Oak Ridge National Laboratory, Oak Ridge, TN 37831-6151.

${ }^{2}$ Retired from Oak Ridge National Laboratory. 
Prevention of reactor pressure vessel (RPV) failure in light-water moderated nuclear power reactors depends primarily on maintaining the RPV material fracture toughness at levels that will resist fracture, elther brittle or ductile, during plant operation, including normal and emergency conditiors. When RPV steels exhibit charpy V-notch (CVN) upper-shelf energy levels of less than $68 \mathrm{~J}$, the requirements of Title 10, Code of Federal Regulations, Part 50 (10CFR50), Appendix G (1) are not met. The regulations require, as an option, that a fracture mechanics analysis be performed that conservatively demonstrates adequate safety margins for continued operation. An acceptable method of analysis is described in the report (2) covering Generic safety Issue A-11 on Reactor Vessel Materials Toughness. In resolving this issue, the U.S. Nuclear Regulatory Commission (NRC) has suggested that, under elastic-plastic conditions, the vessel be evaluated in terms of the tearing instability concept of Paris et al. (3). Merkle has recently provided an overview of the safety margin issue associated with low upper-shelf toughness materials in RPVB (4).

A number of reactor vessels in commercial pressurized water reactor plants fabricated by Babcock and Wilcox Co. (B\&W) include welds with both relatively low initial Charpy upper-shelf energies and high copper concentrations that make them highly sensitive to neutron irradiation. As a result the charpy upper-shelf energies of many welds are expected to fall below $68 \mathrm{~J}$ (50 ft-lb) prior to reaching design Iife. The Heavy-Section Steel Technology (HSST) Program Second and Third HSST Irradiation Series (now designated the Heavy-Section Steel Irradiation (HSSI) Program Second and Third Irradiation Series) were conducted to examine irradiation effects on the elastic-plastic fracture toughness of such welds. This paper presents results from these irradiation experiments with seven "low upper-shelf" weld metals and incorporated tensile and CVN impact tests. A more detailed presentation is given in ref. 5 while ref. 6 provides a summary of all the irradiation series conducted under the HSST program.

\section{EXPERIMENT CONCEPT}

The materials for these experiments were chosen to represent critical early (before 1972) RPV welds, 1.e., they should have CVN upper-shelf energy levels of about $68 \mathrm{~J}$ (50 ft-lb) after irradiation. The largest practical fracture toughness specimen that could be irradiated, considering many factors, was a 101.6-mm-thick compact specimen (4TC(T)] [7]. (The Irradiation capsules were rotated $180^{\circ}$ during the irradiation period to keep the neutron fluence distribution in the large specimens as symmetrical as possible.) In addition to the $4 T C(T)$ fracture toughness specimens, $0.5,0.8$, and $1.6 \mathrm{TC}(\mathrm{T})(12.7,20.3$, and $40.6 \mathrm{~mm}$ thick, respectively), CVN and tensile specimens were included in the irradiation capsules to provide data on $5 i z e$ effects and facilitate correlation of tearing resistance with charpy upper-shelf results. Charpy and tensile specimens were installed in the notches and loading holes of the $4 T C(T)$ specimens to conserve irradiation space. The Irradiations were conducted in the Bulk Shielding Reactor at ORNL, a 2-MW pool-type reactor. The target fast neutron fluence was $1 \times 10^{19}$ neutrons $/ \mathrm{cm}^{2}(>1 \mathrm{MeV})$ at an irradiation temperature of $288^{\circ} \mathrm{C}$ $\left(550^{\circ} \mathrm{F}\right)$.

\section{MATERIALS}

The seven submerged-arc welds in this study, identified as HSST $61 \mathrm{~W}$ through $67 \mathrm{~W}$, were fabricated with materials and procedures used in early pressurized-water reactor (PWR) pressure vessels. These welds had average copper levels ranging from 0.21 to 0.428 with nickel levels of around 0.68 and, thus, were considered "sensitive" to neutron Irradiation embrittlement and typical of some early pressure vessel welds. The use of Iinde 80 flux produced welds with large contents of 
very small inclusions. Although this results in the welds having improved radiographs, they will have relatively low upper-shelf charpy energies in the unirradiated condition. All seven welds were made with 3.17-mm-diam (0.125-in.) MnMoNi copper-coated wire. Complete welding parameter information was supplied only for weld HSST $62 \mathrm{~W}$ (8). The following welding parameterg were employed for this weld:

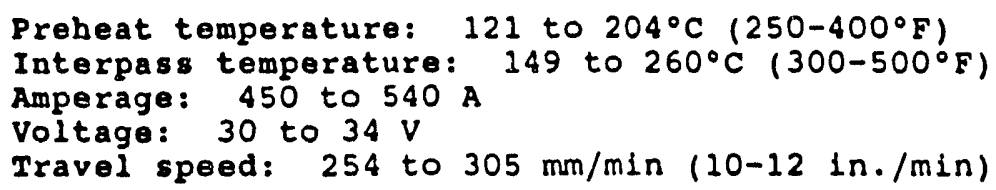

Although complete welding parameter information for the other welds is not available, it may be assumed that they are close to the above parameters. The welding of all welds was an automatic single-wire submerged-arc process (multiple pass).

Postweld stress relief treatments were as follows 19j:

\section{Weld Stress Relief}

$61 \mathrm{~W} \quad 25 \mathrm{~h}$ at 593 to $621^{\circ} \mathrm{C}\left(1100-1150^{\circ} \mathrm{F}\right)$

$62 \mathrm{~W} 8$ cycles of $6 \mathrm{~h}$ at 593 to $621^{\circ} \mathrm{C}\left(1100-1150^{\circ} \mathrm{F}\right)$

$63 \mathrm{~W} \quad 48 \mathrm{~h}$ at 593 to $621^{\circ} \mathrm{C}\left(1100-1150^{\circ} \mathrm{F}\right)$

$64 \mathrm{~W} \quad 48 \mathrm{~h}$ at 593 to $621^{\circ} \mathrm{C}\left(1100-1150^{\circ} \mathrm{F}\right)$

$65 \mathrm{~W} \quad 80 \mathrm{~h}$ at 593 to $621^{\circ} \mathrm{C}\left(1100-1150^{\circ} \mathrm{F}\right)$

$66 \mathrm{~W} \quad 48 \mathrm{~h}$ at 593 to $621^{\circ} \mathrm{C}\left(1100-1150^{\circ} \mathrm{F}\right)$

$67 \mathrm{~W}$ not available

Chemical compositions for the welds are presented in Table 1. For $62 W$, one weld wire (A) was used for a fraction of the through-thickness weld, while a different weld wire (B) was used for the remainder. All Charpy and tensile test specimens were machined from weld wire B (HSST $62 \mathrm{WB}$ ) and no Charpy data for weld wire A (HSST 62WA) are available.

\section{SPECIMEN DESIGNS AND WELDMENT CUTTING}

All test specimens were prepared by the suppliers (Westinghouse Electric Corp. and $B \& W)$. The miniature tensile test specimens are shown in Fig. 1 and were designed to the overall size of a charpy test opecimens to $f i t$ into the irradiation capsules. Two lengths of specimens were used to $\mathrm{fit}$ in the available spaces in the irradiation capsules. The Charpy specimens were ASTM standard CVN impact specimens (type A).

\section{IRRADIATION CAPSULE DESIGN AND OPERATION}

The design of the irradiation capsules was based on the design of the capsules used in the First HSST Irradiation Series $[7,10]$ conducted by Westinghouse Electric Corp. at the Battelle Research Reactor (BRR). Because of neutron flux gradients through the $101.6-\mathrm{mm}$ (4-in.) thickness of the largest specimeng, the capsule design provided for $180^{\circ}$ rotation of the capsules periodically during the irradiations. This rotation was scheduled to provide the same neutron fluences on both faces of the $4 \mathrm{TC}(\mathrm{T})$ specimens. The capsules were exposed in the original orientation for the first 408 of the total irradiation period, exposed in the $180^{\circ}$ rotated position for an additional 508 of the total irradiation period, and back to the original position for the final 108 of the total irradiation period. The resulting fast neutron fluence profile at the crack front of a $4 \mathrm{TC}(\mathrm{T})$ specimen revealed a through-thickness deviation of about $\pm 20 \%$. Each capsule also contained an array of neutron activation dosimeters to provide postirradiation fluence data. The neutron flux for the specimeng varied dependent on location in the capsule but averaged about $1 \times 10^{12}$ neutrons $/ \mathrm{cm}^{2}$ (>1 MeV) (11). 
TABLE 1--Chemical composition of HSSI welds $61 \mathrm{~W}$ through $67 \mathrm{~W}$

\begin{tabular}{|c|c|c|c|c|c|c|c|c|c|c|}
\hline \multirow{2}{*}{ Weld } & \multicolumn{10}{|c|}{$\begin{array}{c}\text { Average composition } \\
\text { (wt \%) }\end{array}$} \\
\hline & C & $\mathrm{Mn}$ & $P$ & $S$ & $\mathrm{Si}$ & $\mathrm{Cr}$ & $\mathrm{Ni}$ & Mo & $\mathrm{Cu}$ & $v$ \\
\hline \multirow{3}{*}{$61 W$} & 0.09 & 1.48 & 0.020 & 0.014 & 0.57 & 0.16 & 0.63 & 0.37 & 0.23 & 0.005 \\
\hline & $\underline{0.07}$ & 1.45 & $\underline{0.018}$ & 0.014 & $\underline{0.55}$ & $\underline{0.16}$ & $\underline{0.62}$ & 0.36 & $\underline{0.26}$ & 0.005 \\
\hline & $\overline{0.10}$ & $\overline{1.52}$ & $\overline{0.021}$ & $\overline{0.015}$ & $\overline{0.58}$ & $\overline{0.17}$ & 0.64 & 0.38 & $\overline{0.31}$ & 0.005 \\
\hline \multirow[t]{3}{*}{$62 W^{b}$} & 0.083 & 1.51 & 0.016 & 0.007 & 0.59 & 0.120 & 0.537 & 0.377 & 0.210 & 0.010 \\
\hline & $\underline{0.078}$ & 1.41 & 0.013 & 0.007 & $\underline{0.55}$ & 0.067 & 0.490 & 0.365 & 0.160 & 0.010 \\
\hline & $\overline{0.088}$ & 1.61 & 0.020 & $\overline{0.008}$ & 0.63 & $\overline{0.173}$ & 0.585 & 0.390 & 0.260 & 0.011 \\
\hline \multirow[t]{3}{*}{$62 W A^{\circ}$} & 0.083 & 1.51 & 0.013 & 0.007 & 0.59 & 0.075 & 0.510 & 0.377 & 0.200 & 0.010 \\
\hline & 0.078 & 1.41 & 0.012 & 0.007 & $\underline{0.55}$ & 0.070 & $\underline{0.480}$ & $\underline{0.365}$ & 0.140 & 0.010 \\
\hline & $\overline{0.088}$ & 1.61 & $\overline{0.014}$ & $\overline{0.008}$ & 0.63 & $\overline{0.090}$ & 0.540 & 0.390 & 0.270 & 0.011 \\
\hline \multirow[t]{3}{*}{$62 W B^{b}$} & 0.083 & 1.51 & 0.018 & 0.007 & 0.59 & 0.170 & 0.550 & 0.377 & 0.177 & 0.011 \\
\hline & 0.078 & 1.41 & $\underline{0.016}$ & 0.007 & 0.55 & $\underline{0.160}$ & 0.540 & 0.365 & 0.160 & 0.010 \\
\hline & 0.088 & 1.61 & 0.020 & 0.008 & 0.63 & 0.180 & 0.600 & 0.390 & 0.230 & 0.012 \\
\hline \multirow[t]{3}{*}{$63 \mathrm{~W}$} & 0.098 & 1.65 & 0.016 & 0.011 & 0.630 & 0.095 & 0.685 & 0.427 & 0.299 & 0.007 \\
\hline & $\underline{0.088}$ & 1.62 & 0.015 & $\underline{0.010}$ & $\underline{0.580}$ & $\underline{0.073}$ & 0.663 & $\underline{0.415}$ & 0.272 & 0.006 \\
\hline & $\overline{0.109}$ & $\overline{1.67}$ & $\overline{0.017}$ & $\overline{0.013}$ & $\overline{0.675}$ & $\overline{0.118}$ & $\overline{0.707}$ & $\overline{0.440}$ & $\overline{0.326}$ & $\overline{0.008}$ \\
\hline \multirow[t]{3}{*}{$64 \mathrm{~W}$} & 0.085 & 1.59 & 0.014 & 0.015 & 0.520 & 0.092 & 0.660 & 0.420 & 0.350 & 0.006 \\
\hline & 0.070 & 1.54 & 0.012 & $\underline{0.014}$ & 0.445 & 0.074 & $\underline{0.600}$ & 0.410 & 0.310 & 0.005 \\
\hline & $\overline{0.100}$ & $\overline{1.64}$ & $\overline{0.017}$ & $\overline{0.016}$ & $\overline{0.600}$ & $\overline{0.110}$ & $\overline{0.720}$ & $\overline{0.430}$ & $\overline{0.390}$ & $\overline{0.008}$ \\
\hline \multirow[t]{3}{*}{$65 \mathrm{~W}$} & 0.080 & 1.45 & 0.015 & 0.015 & 0.480 & 0.088 & 0.597 & 0.385 & 0.215 & 0.006 \\
\hline & $\underline{0.070}$ & 1.42 & 0.014 & $\underline{0.013}$ & 0.450 & 0.076 & 0.585 & 0.370 & 0.180 & 0.005 \\
\hline & $\overline{0.090}$ & $\overline{1.49}$ & 0.017 & $\overline{0.017}$ & $\overline{0.610}$ & 0.100 & $\overline{0.610}$ & $\overline{0.400}$ & $\overline{0.250}$ & 0.008 \\
\hline \multirow[t]{3}{*}{$66 \mathrm{~W}$} & 0.092 & 1.63 & 0.018 & 0.009 & 0.540 & 0.105 & 0.595 & 0.400 & 0.420 & 0.009 \\
\hline & 0.075 & $\underline{1.59}$ & $\underline{0.017}$ & 0.009 & $\underline{0.480}$ & $\underline{0.090}$ & $\underline{0.580}$ & $\underline{0.380}$ & $\underline{0.350}$ & $\underline{0.007}$ \\
\hline & 0.010 & $\overline{1.67}$ & 0.020 & 0.010 & $\overline{0.600}$ & 0.120 & 0.610 & $\overline{0.420}$ & $\overline{0.490}$ & $\overline{0.012}$ \\
\hline \multirow[t]{3}{*}{$67 \mathrm{~W}$} & 0.082 & 1.44 & 0.011 & 0.012 & 0.500 & 0.089 & 0.590 & 0.390 & 0.265 & 0.007 \\
\hline & 0.070 & 1.40 & 0.010 & 0.012 & $\underline{0.410}$ & 0.067 & 0.580 & 0.370 & $\underline{0.220}$ & 0.005 \\
\hline & $\overline{0.095}$ & $\overline{1.48}$ & $\overline{0.013}$ & $\overline{0.013}$ & $\overline{0.590}$ & 0.110 & $\overline{0.600}$ & $\overline{0.410}$ & $\overline{0.310}$ & $\overline{0.010}$ \\
\hline 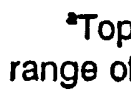 & 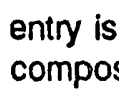 & 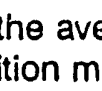 & 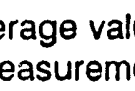 & while & & & & & adinest & \\
\hline
\end{tabular}



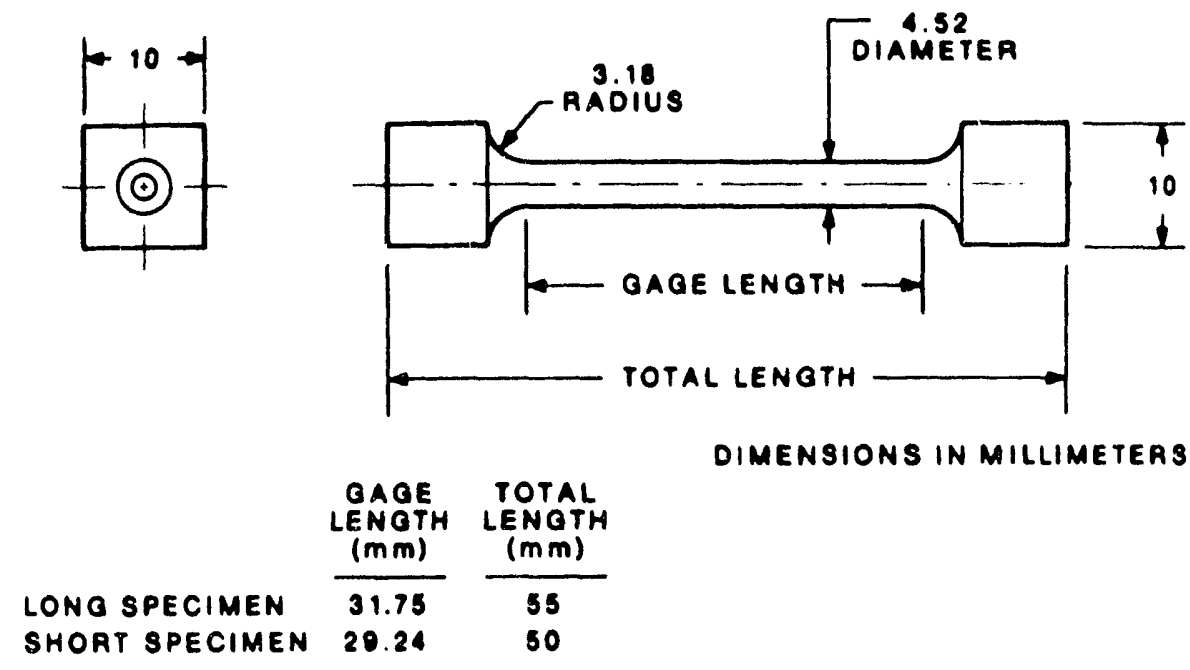

DIMENSIONS IN MILLIMETERS

FIG. 1--Tensile specimen configurations used in the second and Third HSSI Irradiation Series.

The subcapsules installed in the notches of the 4TC(T) specimen contained $0.5 \mathrm{TC}(\mathrm{T}), \mathrm{CVN}$, and tensile specimens. The primary temperature control was at the fatigue crack front of the 4TC(T) specimens. Since there was no independent control of temperatures for the small specimens, they operated at temperatures above or below the desired temperatures, depending on their location in the capsules and the degree of thermal contact between them and the $4 \mathrm{TC}(\mathrm{T})$ specimens. An extreme example of temperature distribution in a capsule is shown in Fig. 2 . Temperatures in this capsule ranged from 238 to $346^{\circ} \mathrm{C}\left(460-655^{\circ} \mathrm{F}\right)$ in the forward position and from 254 to $340^{\circ} \mathrm{C}\left(490-645^{\circ} \mathrm{F}\right)$ in the reverse position. Although the temperatures in the central region of the $4 \mathrm{TC}(\mathrm{T})$ crack fronts are near the desired $288^{\circ} \mathrm{C}\left(550^{\circ} \mathrm{F}\right)$, the extreme temperatures were recorded for the small specimens. Thus, the irradiation temperature for each specimen is an average of the temperatures experienced in the forward and reverse positions. The temperature variation for some specimens was a much as $\pm 25^{\circ} \mathrm{C}\left( \pm 45^{\circ} \mathrm{F}\right)$, but a more typical variation was $\pm 8^{\circ} \mathrm{C}\left( \pm 15^{\circ} \mathrm{F}\right)$. Becauge irradiation embrittlement is dependent on irradiation temperature, these variations would affect the results. In this study, however, no attempt was made to account for the variable temperature exposures for the individual specimens. Additional details of capsule design and operation are contained in ref. 5 .

\section{TEST PROCEDURES}

Tensile tests of specimens from the Second HSSI Irradiation Series (welds HSST $61 \mathrm{~W}, 62 \mathrm{~W}$, and $63 \mathrm{~W}$ ) were conducted by Hanford Engineering Development Laboratory (HEDL) and tests from the Third HSSI Irradiation Series (welds HSST $64 \mathrm{~W}, 65 \mathrm{~W}, 66 \mathrm{~W}$, and $67 \mathrm{~W}$ ) were conducted by Oak Ridge National Laboratory (ORNL). Reference 12 provides details of test procedures and results for the fracture toughness tests.

\section{Tensile Tests}

The tensile test procedures used by HEDL for specimens of welds HSST- $61 W,-62 W$, and $-63 W$, and by ORNL for HSST $-64 W,-65 W,-66 W,-67 W$, are given elsewhere $(13,14)$. Tests at HEDL on both unirradiated and irradiated specimens were conducted at room temperature, 149 , and $288^{\circ} \mathrm{C}$ using an extensometer. Specimen strain rates calculated from extensometer data were in the range of $10^{-1}$ to $10^{-3} / \mathrm{s}$. Tests at oRNL 


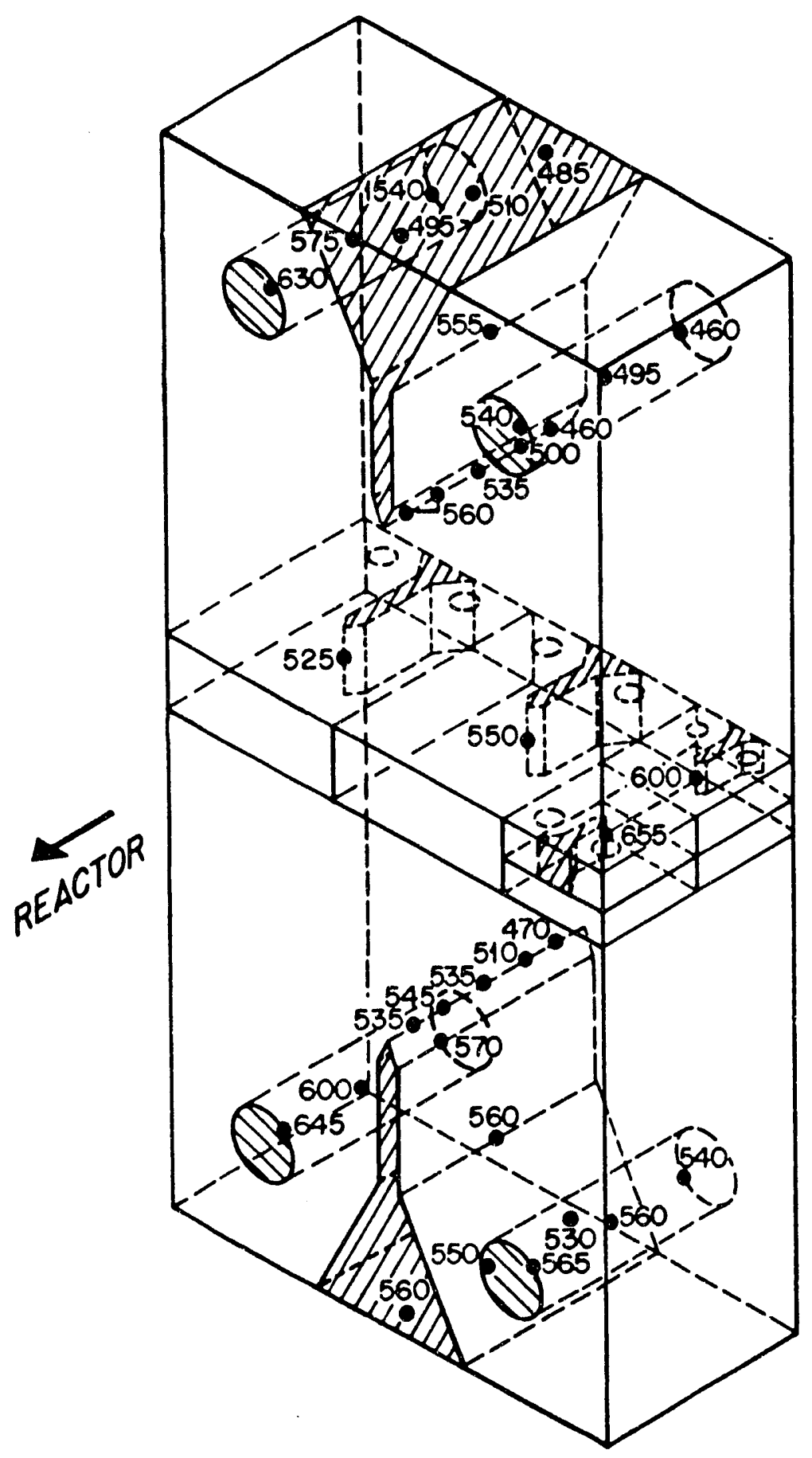

FIG. 2--Extreme example of wide temperature distribution in one capsule of the Second HSSI Irradiation Series, forward position. 
were conducted at the same temperatures used for the HEDL tests. An extensometer was not used and yield strengths were based on crosshead displacement data. Errors in yield strength values determined from crosshead displacement were established to be less than 38 by use of an extensometer at room temperature [14]. Specimen strain rates, based on crosshead displacements, were 2.7 to $2.9 \times 10^{-4} / 8$.

\section{Charpy V-Notch Impact Testg}

Charpy $V$-notch impact tests were conducted by ORNL in accordance with ASTM standard Practice $\mathrm{E}$ 184. The testing machines were calibrated using standard specimens (15) and were instrumented to provide load-time records for each test. In addition to visual estimation of percent ductile fracture, the load-time records were used to estimate the percent ductile fracture in each specimen through a correlation with the fast load drop $[16,17]$. In order to compare impact maciines, the hot cell machine was also used for some of the unirradiated specimens.

\section{RESULTS AND DISCUSSION}

\section{Tensile Testg}

Table 2 provides a summary of the unirradiated results by test temperature for each weld. As stated earlier, the irradiation temperatures for the various tensile specimens were quite varied. Because the normal operating temperature of RPVs is considered to be $288^{\circ} \mathrm{C}$, the tensile data were analyzed to allow for estimates of the irradiation-induced increases in the yield and ultimate strengths at the irradiation temperature of $288^{\circ} \mathrm{C}$. Not all of the welds were represented by adequate numbers of test results for such analysis. To provide a comprehensive analysis of all the tensile results for the seven welds, the room temperature results for $61 \mathrm{~W}$ through $63 \mathrm{~W}$ were used to obtain average changes ys irradiation temperature. The resulting average changes were $-1.15 \mathrm{MPa} /{ }^{\circ} \mathrm{C}$ for yield strength, $-0.79 \mathrm{MPa} /{ }^{\circ} \mathrm{C}$ for ultimate strength, and $-0.0148 /{ }^{\circ} \mathrm{C}$ for total elongation. Table 3 provides a summary of the irradiated tensile results for each weld adjusted to an irradiation cemperature of $288^{\circ} \mathrm{C}$. The results not annotated by a note were taken directly from the actual value obtained from the regression analysis. The annotated results were obtained by adjusting the observed test results for irradiation temperature using the multipliers given above.

Then, because the available data were not generally adequate for fluence normalization using the individual data points as described earlier, all the data from Table 3 were adjusted to a fluence of $8 \times 10^{18}$ neutrons $/ \mathrm{cm}^{2}$. Using the typical square root dependence on fluence (18) for the irradiation-induced yield strength change resulted in strength increases that did not appear reasonable. Thus, the irradiation-induced yield strength changes obtained at an irradiation temperature of $288^{\circ} \mathrm{C}\left( \pm 4^{\circ} \mathrm{C}\right)$ were plotted vs neutron fluence and fit to a power curve. The result showed a very low dependence on fluence for these welds over the fluence range examined 14.5 to $11.4 \times 10^{18}$ neutrong $\left./ \mathrm{cm}^{2}(>1 \mathrm{MeV})\right)$. The exponent obtained by the analysis was 0.07 and the differences in strength (the ultimate strength changes were normalized using the same factor) between the unirradiated values in Table 2 and the irradiated values in Table 3 were multiplied by the factor, $\left(8 \times 10^{18} / \text { Average Fluence }\right)^{0.07}$. In this way, a consistently analyzed set of tensile results are presented in Table 4 for all seven welds and represent best estimates of the tensile properties for welds $61 \mathrm{~W}$ through $67 \mathrm{~W}$ irradiated at $288^{\circ} \mathrm{C}$ to a fluence of $8 \times 10^{18}$ neutrons $/ \mathrm{cm}^{2}$. The fluences are varied and the average values are given in Table 3. Figure 3 shows a plot of the normalized results compared to the unirradiated curves for weld $61 \mathrm{~W}$. The total elongation results were not normalized for fluence. Similar plots for the other welds are given in ref. 5 . 
TABLE 2--Summary of unirradiated tensile resultg for HSSI welds $61 \mathrm{~W}$ through $67 \mathrm{~W}$

\begin{tabular}{|c|c|c|c|c|c|c|}
\hline \multirow{2}{*}{ Weld } & \multirow{2}{*}{$\begin{array}{c}\text { Test } \\
\text { temperature } \\
\left({ }^{\circ} \mathrm{C}\right)\end{array}$} & \multicolumn{2}{|c|}{$\begin{array}{c}\text { Strength } \\
\text { (MPa) }\end{array}$} & \multirow{2}{*}{$\begin{array}{l}\text { Uniform } \\
\text { strain } \\
(\%)\end{array}$} & \multirow{2}{*}{$\begin{array}{c}\text { Reduction } \\
\text { in area } \\
(\%)\end{array}$} & \multirow{2}{*}{$\begin{array}{c}\text { Total } \\
\text { elongation } \\
(\%)\end{array}$} \\
\hline & & Yield & Ultimate & & & \\
\hline \multirow[t]{3}{*}{$61 W$} & 26 & 480 & 599 & 10.4 & 65.8 & 18.4 \\
\hline & 149 & 444 & 548 & 8.3 & 65.4 & 17.7 \\
\hline & 288 & 418 & 536 & 7.0 & 63.8 & 16.0 \\
\hline \multirow[t]{3}{*}{$62 W$} & 26 & 473 & 591 & 9.9 & 66.0 & 18.8 \\
\hline & 149 & 428 & 534 & 9.4 & 68.6 & 15.8 \\
\hline & 288 & 385 & 514 & 8.0 & 63.5 & 14.7 \\
\hline \multirow[t]{3}{*}{$63 W$} & 26 & 482 & 600 & 10.2 & 66.4 & 20.4 \\
\hline & 149 & 432 & 545 & 8.6 & 67.2 & 18.0 \\
\hline & 288 & 410 & 530 & 7.6 & 63.4 & 16.6 \\
\hline \multirow[t]{3}{*}{$64 \mathrm{~W}$} & 27 & 465 & 580 & 9.9 & 64.8 & 18.9 \\
\hline & 150 & 417 & 530 & 9.7 & 66.5 & 17.8 \\
\hline & 288 & 398 & 543 & 8.9 & 54.7 & 15.4 \\
\hline \multirow[t]{3}{*}{$65 \mathrm{~W}$} & 27 & 457 & 571 & 9.7 & 65.1 & 18.1 \\
\hline & 150 & 423 & 533 & 7.7 & 64.2 & 15.3 \\
\hline & 288 & 412 & 549 & 8.2 & 58.0 & 14.8 \\
\hline \multirow[t]{3}{*}{$66 \mathrm{~W}$} & 27 & 534 & 639 & 7.6 & 63.4 & 16.0 \\
\hline & 150 & 506 & 597 & 6.7 & 64.2 & 14.1 \\
\hline & 288 & 498 & 608 & 6.6 & 46.6 & 12.2 \\
\hline \multirow[t]{3}{*}{$67 \mathrm{~W}$} & 27 & 462 & 583 & 9.4 & 66.5 & 17.9 \\
\hline & 150 & 429 & 542 & 6.8 & 65.5 & 14.3 \\
\hline & 288 & 430 & 562 & 9.9 & 57.9 & 13.5 \\
\hline
\end{tabular}

The final adjusted results were all fit with second-order polynomials and the curve fit coefficients are given in ref. 5 . Table 5 provides a summary of the radiation-induced changes in the yield and ultimate strengths of those welds, expressed both in terms of the measured strength changes and as percentage changes at the three nominal test temperatures. As the table shows, irradiation-induced strength increases at room temperature range from 107 to $162 \mathrm{MPa}$ for yield strength and from 86 to $123 \mathrm{MPa}$ for ultimate strength. Relative to the unirradiated strengths, those changes represent increases of 20.8 to 35.18 for yield strength and 13.5 to 20.58 for ultimate strength. Thus, the changes in yield strength were greater than those for ultimate strength, as is usually observed.

\section{Charpy V-Notch Impact Tests}

As mentioned earlier, some unirradiated specimens from each weld were tested on the machine in the hot cell to allow for a determination of machine differences. Figure 4 shows a plot of the CVN energy va test temperature for unirradiated weld $61 \mathrm{~W}$. The curves shown are fits to each data set using a hyperbolic tangent function that includes partial 
TABLE 3--Summary of Irradiated tensile results for HSSI welds $61 \mathrm{~W}$ through $67 \mathrm{~W}$ adjusted to an irradiation temperature of $288^{\circ} \mathrm{C}$

\begin{tabular}{|c|c|c|c|c|c|c|}
\hline \multirow{2}{*}{ Weld } & \multirow{2}{*}{$\begin{array}{c}\text { Test } \\
\text { temperature } \\
\left({ }^{\circ} \mathrm{C}\right)\end{array}$} & \multirow{2}{*}{$\begin{array}{c}\text { Fluence } \\
\left(\mathrm{n} / \mathrm{cm}^{2} \times 10^{-19}\right)\end{array}$} & \multirow{2}{*}{$\begin{array}{c}\text { Number } \\
\text { of } \\
\text { tests }\end{array}$} & \multicolumn{2}{|c|}{$\begin{array}{l}\text { Strength } \\
\text { (MPa) }\end{array}$} & \multirow{2}{*}{$\begin{array}{c}\text { Total } \\
\text { elongation } \\
(\%)\end{array}$} \\
\hline & & & & Yield & Ultimate & \\
\hline $61 W$ & $\begin{array}{r}30 \\
150 \\
288\end{array}$ & $\begin{array}{r}9.2 \\
11.9 \\
9.5\end{array}$ & $\begin{array}{l}6 \\
1 \\
2\end{array}$ & $\begin{array}{l}528 \\
562^{b} \\
527\end{array}$ & $\begin{array}{l}723 \\
663^{b} \\
647\end{array}$ & $\begin{array}{l}17.7 \\
17.3^{b} \\
16.4\end{array}$ \\
\hline $62 W$ & $\begin{array}{r}30 \\
150 \\
288\end{array}$ & $\begin{array}{r}11.4 \\
10.2 \\
9.3\end{array}$ & $\begin{array}{l}5 \\
2 \\
2\end{array}$ & $\begin{array}{l}606 \\
537^{c} \\
479^{c}\end{array}$ & $\begin{array}{l}697^{\circ} \\
631^{c} \\
605^{c}\end{array}$ & $\begin{array}{l}19.0 \\
15.4^{c} \\
15.4^{c}\end{array}$ \\
\hline $63 W$ & $\begin{array}{r}30 \\
150 \\
288\end{array}$ & $\begin{array}{r}9.0 \\
13.1 \\
8.3\end{array}$ & $\begin{array}{l}6 \\
1 \\
2\end{array}$ & $\begin{array}{l}619 \\
576^{d} \\
523\end{array}$ & $\begin{array}{l}709 \\
675^{\circ} \\
640\end{array}$ & $\begin{array}{l}16.9 \\
15.6^{d} \\
16.9\end{array}$ \\
\hline $64 W$ & $\begin{array}{r}30 \\
150 \\
288\end{array}$ & $\begin{array}{l}4.6 \\
6.4 \\
4.5\end{array}$ & $\begin{array}{l}2 \\
1 \\
3\end{array}$ & $\begin{array}{l}596 \\
506^{\circ} \\
526\end{array}$ & $\begin{array}{l}691 \\
614^{\circ} \\
658\end{array}$ & $\begin{array}{l}17.1 \\
14.6^{\circ} \\
12.8\end{array}$ \\
\hline $65 W$ & $\begin{array}{r}30 \\
150 \\
288\end{array}$ & $\begin{array}{l}4.8 \\
4.9 \\
5.2\end{array}$ & $\begin{array}{l}2 \\
2 \\
3\end{array}$ & $\begin{array}{l}560 \\
467 \\
508\end{array}$ & $\begin{array}{l}660 \\
623 \\
638\end{array}$ & $\begin{array}{l}18.4 \\
16.3 \\
15.6\end{array}$ \\
\hline $66 \mathrm{~W}$ & $\begin{array}{r}30 \\
150 \\
288\end{array}$ & $\begin{array}{l}6.4 \\
6.0 \\
7.0\end{array}$ & $\begin{array}{l}2 \\
2 \\
2\end{array}$ & $\begin{array}{l}643^{\prime} \\
596^{\circ} \\
582\end{array}$ & $\begin{array}{l}724^{\prime} \\
684^{\circ} \\
683\end{array}$ & $\begin{array}{l}16.4^{\prime} \\
13.2^{\circ} \\
10.7\end{array}$ \\
\hline $67 \mathrm{~W}$ & $\begin{array}{r}30 \\
150 \\
288 \\
\end{array}$ & $\begin{array}{l}1.8 \\
4.8 \\
6.9 \\
\end{array}$ & $\begin{array}{l}1 \\
2 \\
3 \\
\end{array}$ & $\begin{array}{l}608^{h} \\
552^{\prime} \\
531 \\
\end{array}$ & $\begin{array}{l}687^{h} \\
645^{\prime} \\
656 \\
\end{array}$ & $\begin{array}{l}15.3^{h} \\
13.6^{\prime} \\
13.3 \\
\end{array}$ \\
\hline $\begin{array}{c}\text { ir } \\
\text { Resul } \\
\text { for ult } \\
\\
\\
\\
\end{array}$ & $\begin{array}{l}\text { ufficient data } \\
\text { shown were } \\
\text { mate strength, } \\
7^{\circ} \mathrm{C} \text {. } \\
2^{\circ} \mathrm{C} \text {. } \\
9^{\circ} \mathrm{C} \text {. } \\
3^{\circ} \mathrm{C} \text {. } \\
0^{\circ} \mathrm{C} \text {. } \\
4^{\circ} \mathrm{C} \text {. } \\
4^{\circ} \mathrm{C} \text {. } \\
2^{\circ} \mathrm{C} \text {. }\end{array}$ & $\begin{array}{l}\text { egression at } \\
\text { sted by }-1.14 \\
-0.0136 \% /{ }^{\circ} \mathrm{C}\end{array}$ & 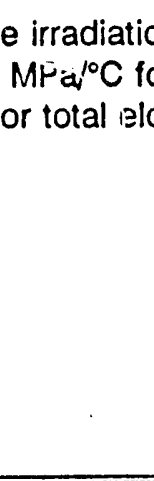 & $\begin{array}{l}\text { emper } \\
\text { eld str } \\
\text { ation. }\end{array}$ & $\begin{array}{l}\text { s indic? } \\
h,-0.79\end{array}$ & $\begin{array}{l}\text { d below. } \\
\mathrm{MPa} /{ }^{\circ} \mathrm{C}\end{array}$ \\
\hline
\end{tabular}


TABLE 4--Summary of irradiated tensile results for HSSI welds $61 \mathrm{~W}$ through $67 \mathrm{~W}$ adjusted to an

irradiation temperature of $288^{\circ} \mathrm{C}$ and fluence of $8 \times 10^{18}$ neutrons $/ \mathrm{cm}^{2}$

\begin{tabular}{|c|c|c|c|c|c|}
\hline \multirow{2}{*}{ Weld } & \multirow{2}{*}{$\begin{array}{c}\text { Test } \\
\text { temperature } \\
\left({ }^{\circ} \mathrm{C}\right)\end{array}$} & \multirow{2}{*}{$\begin{array}{c}\text { Number } \\
\text { of } \\
\text { tests }\end{array}$} & \multicolumn{2}{|c|}{$\begin{array}{c}\text { Strength } \\
\text { (MPa) }\end{array}$} & \multirow{2}{*}{$\begin{array}{c}\text { Total } \\
\text { elongation } \\
(\%)\end{array}$} \\
\hline & & & Yield & Ultimate & \\
\hline \multirow[t]{3}{*}{$61 W$} & 30 & 6 & 626 & 722 & 17.7 \\
\hline & 150 & 1 & 559 & 660 & 17.3 \\
\hline & 288 & 2 & 526 & 646 & 16.4 \\
\hline \multirow[t]{3}{*}{$62 W$} & 30 & 5 & 603 & 694 & 19.0 \\
\hline & 150 & 2 & 535 & 630 & 15.4 \\
\hline & 288 & 2 & 478 & 604 & 15.4 \\
\hline \multirow[t]{3}{*}{$63 W$} & 30 & 6 & 618 & 708 & 16.9 \\
\hline & 150 & 1 & 571 & 671 & 15.6 \\
\hline & 288 & 2 & 523 & 640 & 16.9 \\
\hline \multirow[t]{3}{*}{$64 W$} & 30 & 2 & 601 & 695 & 17.1 \\
\hline & 150 & 1 & 507 & 615 & 14.6 \\
\hline & 288 & 3 & 531 & 663 & 12.8 \\
\hline \multirow[t]{3}{*}{$65 W$} & 30 & 2 & 564 & 663 & 18.4 \\
\hline & 150 & 2 & 468 & 626 & 16.3 \\
\hline & 288 & 3 & 511 & 641 & 15.6 \\
\hline \multirow[t]{3}{*}{$66 W$} & 30 & 2 & 645 & 725 & 16.4 \\
\hline & 150 & 2 & 598 & 686 & 13.2 \\
\hline & 288 & 2 & 583 & 684 & 10.7 \\
\hline \multirow[t]{3}{*}{$67 \mathrm{~W}$} & 30 & 1 & 624 & 698 & 15.3 \\
\hline & 150 & 2 & 557 & 649 & 13.6 \\
\hline & 288 & 3 & 532 & 657 & 13.3 \\
\hline
\end{tabular}

differentials to allow for a sloping upper shelf. As expected, the curve using all the data falls between the other two curves. The upper-shelf energy determined on the hot cell machine was $85 \mathrm{~J}$ compared to about $96 \mathrm{~J}$ determined on the laboratory machine. Similar analyses were performed for welds $62 \mathrm{~W}$ through $67 \mathrm{~W}$ and the results showed the same consistent trends. Both machines met the calibration requirements (15) and the reasong for these consistent machine differences were not ascertained. The 41-J transition temperatures are varied and, because testing in the lower transition region was limited, a comparison is not considered very reliable. Even so, the differences that do result are less than about $20^{\circ} \mathrm{C}$. 


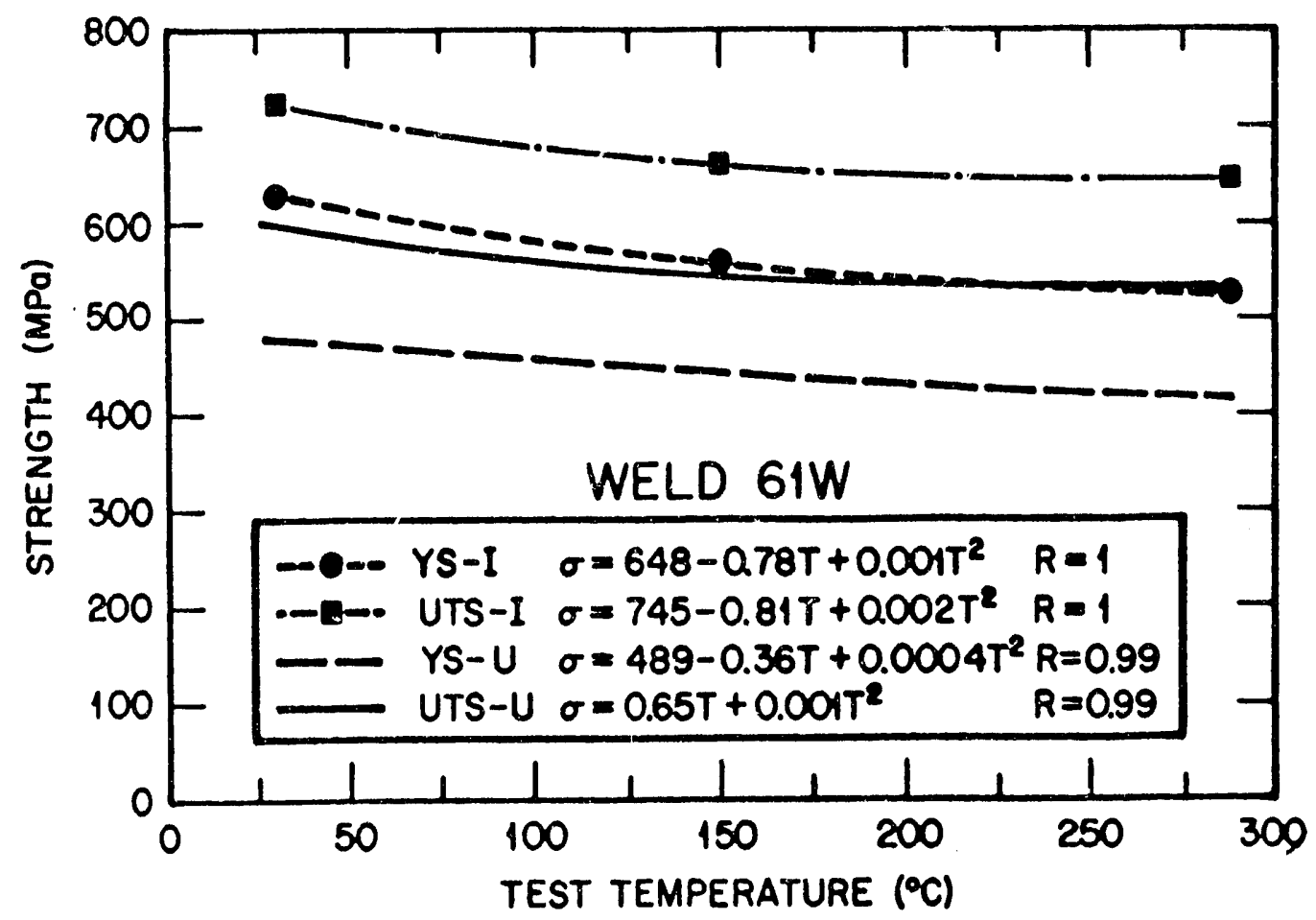

FIG. 3--Average of irradiated yield and ultimate strengths for HSSI weld $61 \mathrm{~W}$ after adjustment for irradiation temperature to $288^{\circ} \mathrm{C}$ and normalized to a fluence of $8 \times 10^{18}$ neutrons $/ \mathrm{cm}^{2}(<1 \mathrm{MeV})$. The unirradiated curves are shown for comparison and the equations of $f$ it shown in the legend are represented by the curves drawn on the graph.

TAB:E 5-- Summary of irradiation effects on tengile properties of HSSI welds $61 \mathrm{~W}$ through $67 \mathrm{~W}$ adjusted to an irradiation temperature of $288^{\circ} \mathrm{C}$ and a fluence of $8 \times 10^{18}$ neutrons $/ \mathrm{cm}^{2}$

\begin{tabular}{||c|c|c|c|c|c|c||}
\hline \multirow{3}{*}{ Weld } & \multicolumn{6}{|c|}{$\begin{array}{c}\text { Strength change, } \\
\text { MPa (\%) }\end{array}$} \\
\cline { 2 - 7 } & \multicolumn{7}{|c||}{ Yield } & & \multicolumn{3}{c||}{ Ultimate } \\
\cline { 2 - 7 } & $30^{\circ} \mathrm{C}$ & $150^{\circ} \mathrm{C}$ & $288^{\circ} \mathrm{C}$ & $30^{\circ} \mathrm{C}$ & $150^{\circ} \mathrm{C}$ & $288^{\circ} \mathrm{C}$ \\
\hline \multirow{2}{*}{$61 \mathrm{~W}$} & $146(30.4)$ & $115(25.9)$ & $108(25.8)$ & $123(20.5)$ & $112(20.4)$ & $108(20.5)$ \\
$62 \mathrm{~W}$ & $130(27.5)$ & $107(25.0)$ & $93(24.1)$ & $103(17.4)$ & $95(17.8)$ & $90(17.5)$ \\
$63 \mathrm{~W}$ & $136(28.2)$ & $139(32.2)$ & $113(27.6)$ & $108(18.0)$ & $126(23.1)$ & $110(20.7)$ \\
$64 \mathrm{~W}$ & $136(29.2)$ & $90(21.6)$ & $133(33.4)$ & $115(19.8)$ & $85(16.0)$ & $120(22.1)$ \\
$65 \mathrm{~W}$ & $107(23.4)$ & $45(10.6)$ & $99(24.0)$ & $92(16.1)$ & $93(17.4)$ & $92(16.7)$ \\
$66 \mathrm{~W}$ & $111(20.8)$ & $92(18.2)$ & $85(17.1)$ & $86(13.5)$ & $89(14.9)$ & $76(12.5)$ \\
$67 \mathrm{~W}$ & $162(35.1)$ & $138(32.2)$ & $102(23.7)$ & $115(19.7)$ & $107(19.7)$ & $95(16.9)$ \\
\hline
\end{tabular}




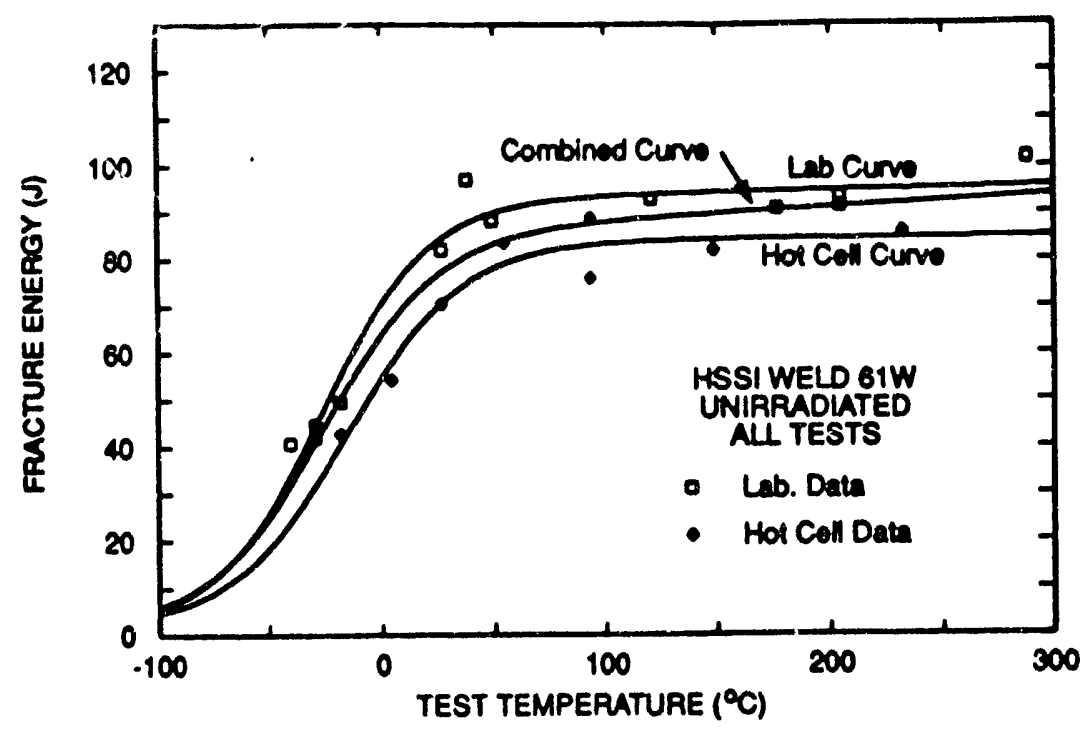

FIG. 4--Unirradiated Charpy V-notch impact energy vg test temperature for HSSI weld $61 \mathrm{~W}$ showing comparison between laboratory test machine and hot cell machine. The curves shown are best fits using a hyperbolic tangent with the lower shelf fixed at $3 \mathrm{~J}$ and a sloping upper shelf.

Because large differences between laboratory and hot cell machine data on the ductile shelf exist for many of the welds, the hot cell machine data will be used as the reference data for unirradiated results. Table 6 provides the upper-shelf energies at $200^{\circ} \mathrm{C}$ and the 41-J transition temperatures for each weld. The 41-J transition temperatures vary from -41 to $13^{\circ} \mathrm{C}\left(-42\right.$ to $\left.55^{\circ} \mathrm{F}\right)$ while the ductile shelf energies vary from 74 to $111 \mathrm{~J}(55-82 \mathrm{ft}-1 \mathrm{~b})$. The lowest unirradiated ductile shelf energy of $74 \mathrm{~J}(55 \mathrm{ft}-1 \mathrm{~b})$ was exhibited by weld $66 \mathrm{~W}$ and is only slightly above the $68-\mathrm{J}$ (50 ft-lb) minimum required by 10 CFR50 for irradiated material. The current minimum unirradiated upper-shelf energy required in 10CFR50 is $102 \mathrm{~J}(75 \mathrm{ft}-1 \mathrm{~b})$. Welds $64 \mathrm{~W}, 65 \mathrm{~W}$, and $67 \mathrm{~W}$ are the only welds that meet that minimum and are at or only slightly above the 102-J level.

TABLE 6--Summary of Charpy 41-J temperature and upper-shelf energy for unirradiated HSSI welds $61 \mathrm{~W}$ through $67 \mathrm{~W}$

\begin{tabular}{||c|r|r|r|c|}
\hline \multirow{2}{*}{ Weld } & \multicolumn{3}{|c|}{ Charpy impact parameters } \\
\cline { 2 - 5 } & \multicolumn{2}{|c|}{41 J temperature } & \multicolumn{2}{|c|}{$\begin{array}{c}\text { Upper-shelf } \\
\text { energy }\end{array}$} \\
\cline { 2 - 5 } & $\left({ }^{\circ} \mathrm{C}\right)$ & $\left({ }^{\circ} \mathrm{F}\right)$ & $(\mathrm{J})$ & $(\mathrm{ft}-1 \mathrm{~b})$ \\
\hline $61 \mathrm{~W}$ & -17 & 1 & 85 & 63 \\
$62 \mathrm{~W}$ & -13 & 9 & 94 & 69 \\
$63 \mathrm{~W}$ & -26 & -15 & 90 & 66 \\
$64 \mathrm{~W}$ & 7 & 45 & 102 & 75 \\
$65 \mathrm{~W}$ & -24 & -11 & 111 & 82 \\
$66 \mathrm{~W}$ & 13 & 55 & 74 & 55 \\
$67 \mathrm{~W}$ & -41 & -42 & 103 & 76 \\
\hline
\end{tabular}


The Irradiated CVN tests were all conducted in the hot cell on the same machine used for the previously presented unirradiated hot cell tests. The lrradiated tests were grouped according to irradiation temperature and the data for each weld were separated according to elther transition region tests or ductile shelf tests (zero fast load drop). Some groups have only one specimen. Within each group, there are also fluence variations. Flgures 5 (a) through $5(f)$ show plots of the irradiated CVN results for weld $61 \mathrm{w}$. The plot with all the data [Fig. 5(a)] shows the large variability through the tegt temperature range, while Figs. 5(b) through $5(f)$ show the data for each group by irradiation temperature. The curve shown in each plot is the hyperbolic tangent fit to the unirradiated data obtained in the hot cell. For welds $62 \mathrm{~W}$ through $67 \mathrm{~W}$, similar plots were produced and are available in ref. 5 .

The data from each irradiated weld were not fit with curves because of the variations in irradiation temperature and neutron fluence. To account for fluence differences, each test result was normalized to a fluence of $8 \times 10^{18}$ neutrons $/ \mathrm{cm}^{2}$. For the transition region data, the normalization was performed by multiplying the observed transition temperature increase $(\Delta T T)$ for each test result (e.g., the temperature difference between the irradiated result and the reference curve for the unirradiated material at the energy level measured as shown in Fig. 5(d)? by the square root of the ratio of $8 \times 10^{18}$ neutrons $/ \mathrm{cm}^{2}$ to the fluence of the test specimen. An exponent of 0.5 was used because that is a typical value for the charpy shift dependence on fluence for pressure vessel steel welds irradiated in test reactors (18). For example, for specimen 61224 the fracture energy was $51.5 \mathrm{~J}$. At that energy level, the temperature increase relative to that of the hyperbolic tangent curve for unirradiated $61 \mathrm{~W}$ was $70.1^{\circ} \mathrm{C}$. After normalization, the temperature increase is $68.9^{\circ} \mathrm{C}$. Normalization decreased the transition temperature change because the fluence for that specimen was greater than $8 \times 10^{18}$. For specimens with fluences lower than $8 \times 10^{18}$, the normalized transition temperature will be greater than the observed value. For the upper-shelf data (test results at 1008 ductile fracture), the normalization was performed in the same manner except that the observed energy change (in percent) will be normallzed to a greater change for specimens with fluences less than $8 \times 10^{18}$.

Figure $6(a)$ shows all the transition temperature region data for $61 \mathrm{~W}$ plotted as the observed transition temperature increase vs irradiation temperature. The hyperbolic tangent curves for each unirradiated weld (based on the unirradiated specimens tested in the hot cell) are used as the reference curves in all the analyses. Thus, the transition temperature increase for each irradiated test result is relative to the unirradiated curve at the measured energy level. Figure $6(b)$ is a similar plot using the results normalized for fluence. Although the results are somewhat scattered, the trend is certainly one of lower transition temperature increases with higher irradiation temperatures. Figures $6(c)$ and $6(d)$ are similar plots for the decrease in ductile shelf energy (percent change). As expected, the effects of irradiation on the ductile shelf energy become less at higher irradiation temperatures. Except for the normalized upper-shelf data for $63 \mathrm{~W}$ and the normalized transition region data for $64 \mathrm{~W}$, the results for all the welds show the same trends of decreasing effects of irradiation with increasing irradiation temperature.

As with the tensile results, the CVN data were analyzed to allow for estimates of the transition temperature and ductile shelf energy changes at an irradiation temperature of $288^{\circ} \mathrm{C}$. For $61 \mathrm{~W}$, for example, this analysis required fitting the observed and normalized results and extrapolating to $288^{\circ} \mathrm{C}$. For other welds, interpolation was used. Both linear and quadratic fits were performed but the range of irradiation temperatures for most of the welds was too small for the quadratic 

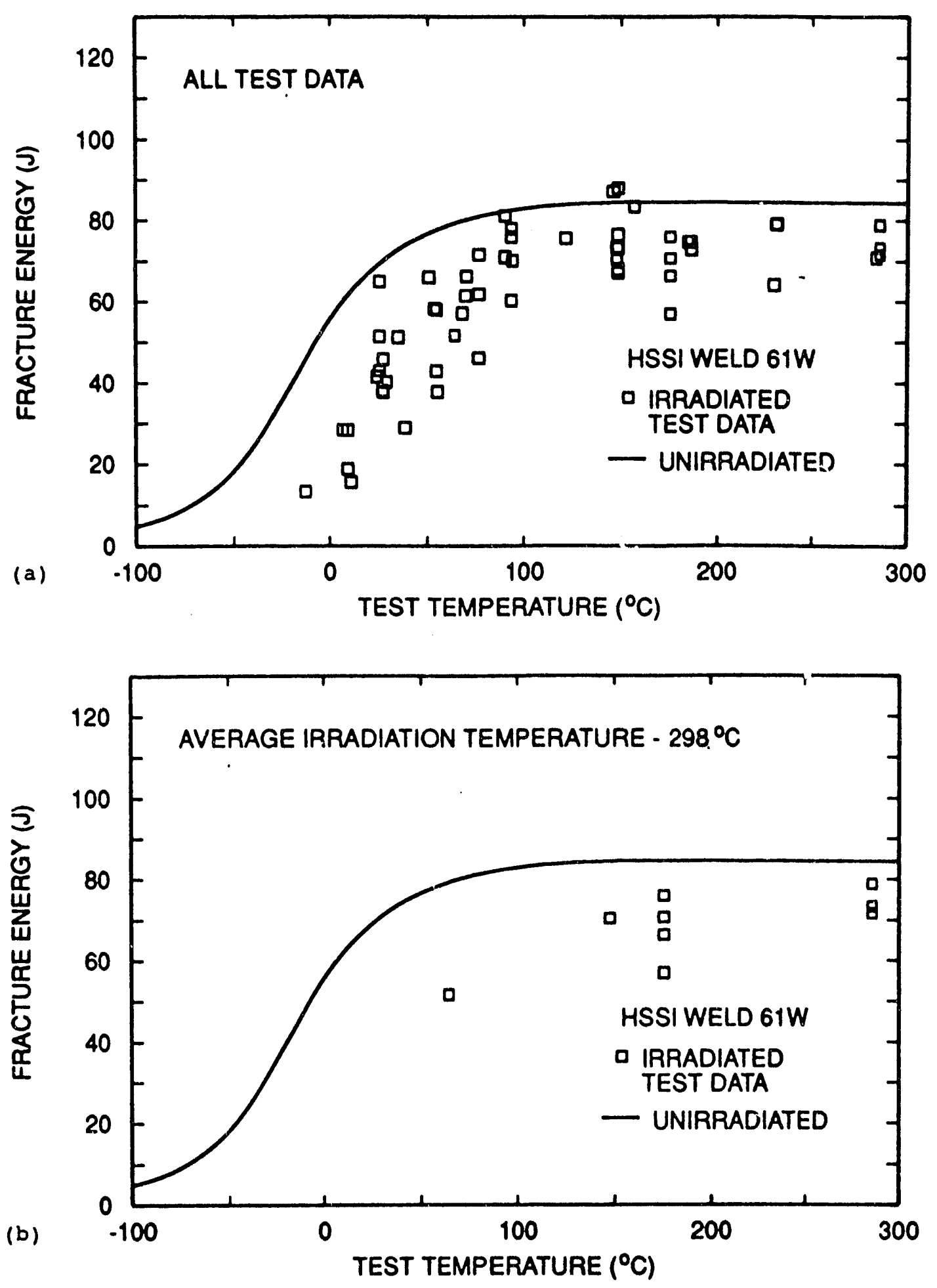

FIG. 5--Irradiated Charpy V-notch impact energy vo test temperature for HSSI weld $61 \mathrm{~W}$ irradiated at various temperatures, (a) all tests, (b) $298^{\circ} \mathrm{C}$, (c) $311^{\circ} \mathrm{C}$, (d) $323^{\circ} \mathrm{C}$, (e) $329^{\circ} \mathrm{C}$, and

(f) $345^{\circ} \mathrm{C}$. The curves show the hyperbolic tangent $f$ it to the data for the unirradiated specimens tested with the hot cell machine. 

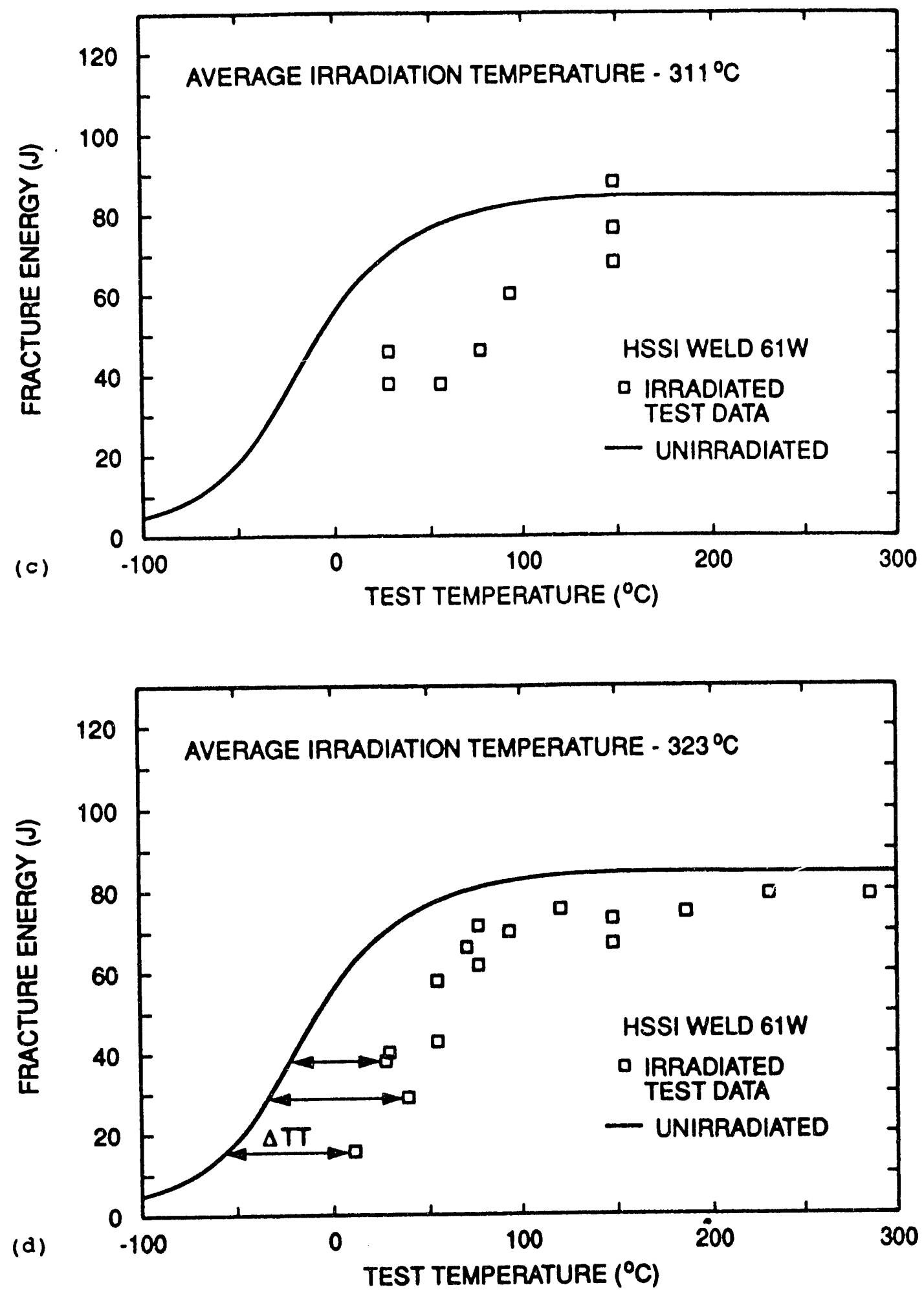

FIG. $5--$ (continued) 

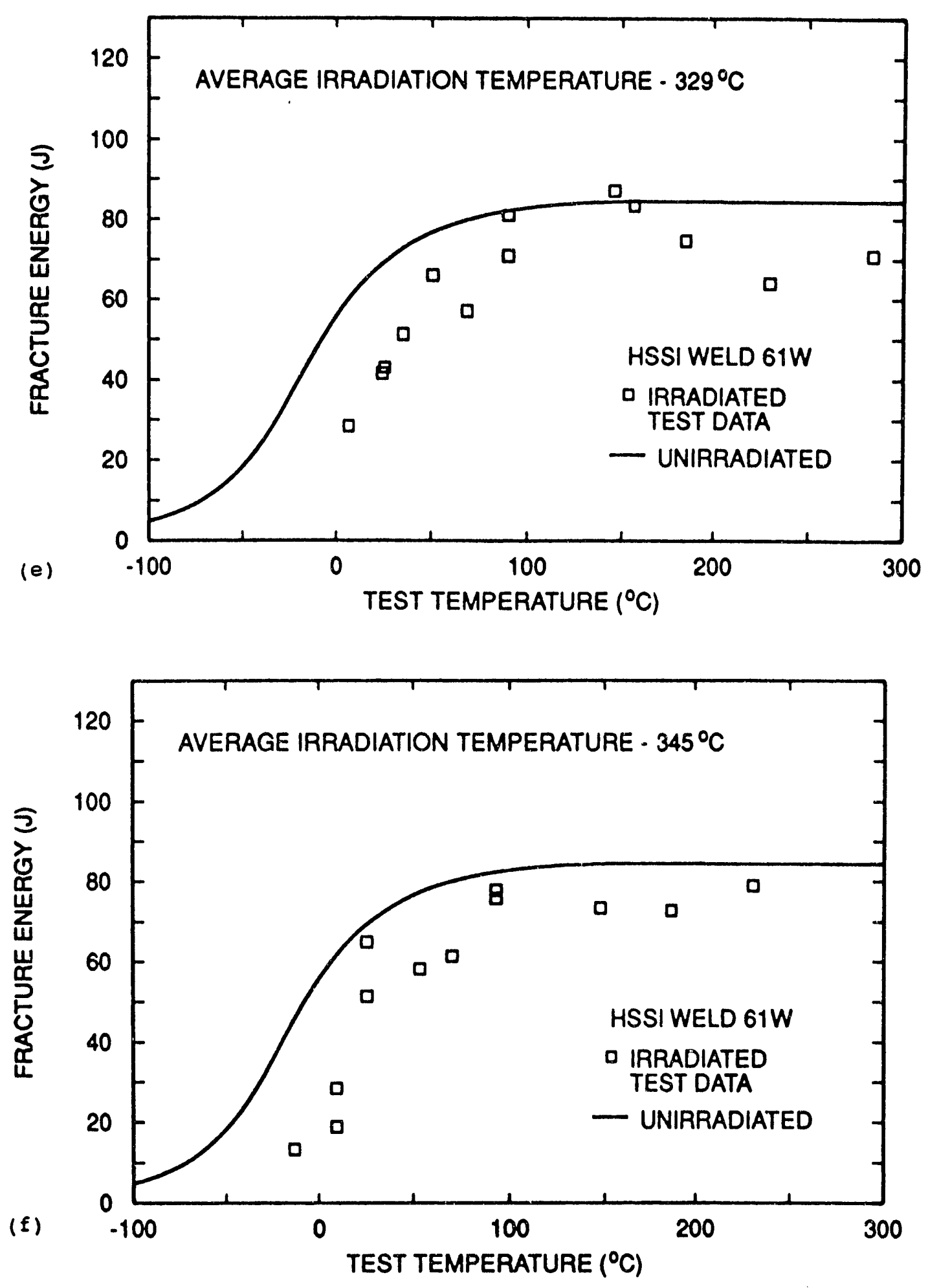

FIG. 5--(continued) 

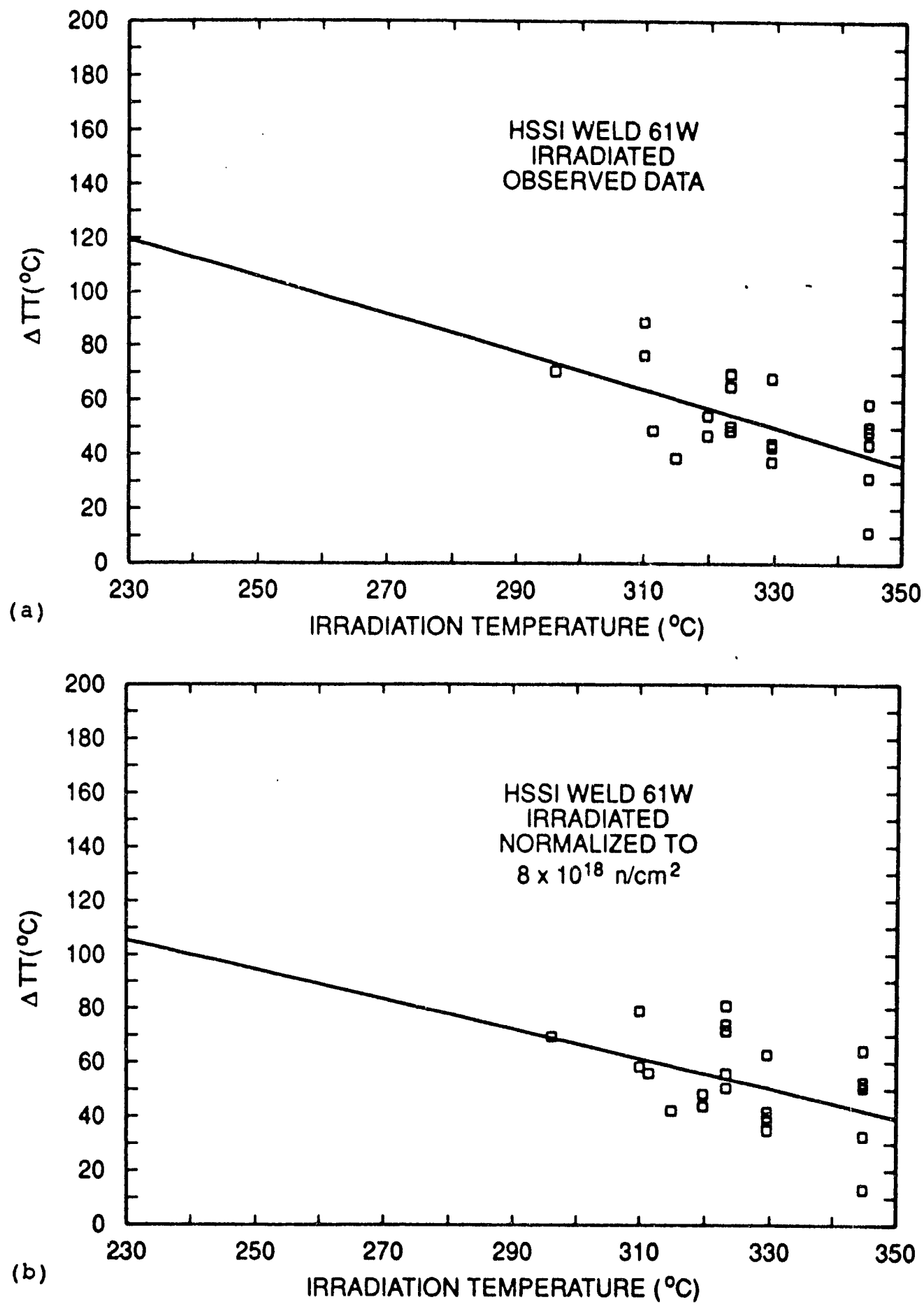

FIG. 6--Radiation-induced change in charpy V-notch impact toughness for HSSI weld 61W, (a) transition temperature increase vs irradiation temperature for all data, (b) transition temperature increase vs Irradiation temperature for data normalized to $8 \times 10^{12}$ neutrons $/ \mathrm{cm}^{2}(>1 \mathrm{MeV})$. (c) upper-shelf energy decrease vs irradiation temperature, and (d) upper-shelf energy decrease vs irradiation temperature for data normalized to $8 \times 10^{18}$ neutrons $/ \mathrm{cm}^{2}$ $(>1 \mathrm{MeV})$. All measures of change are relative to the hyperbolic tangent curve fit to the unirradiated data obtained on the hot cell machine. The curves shown are linear fits to the data. 

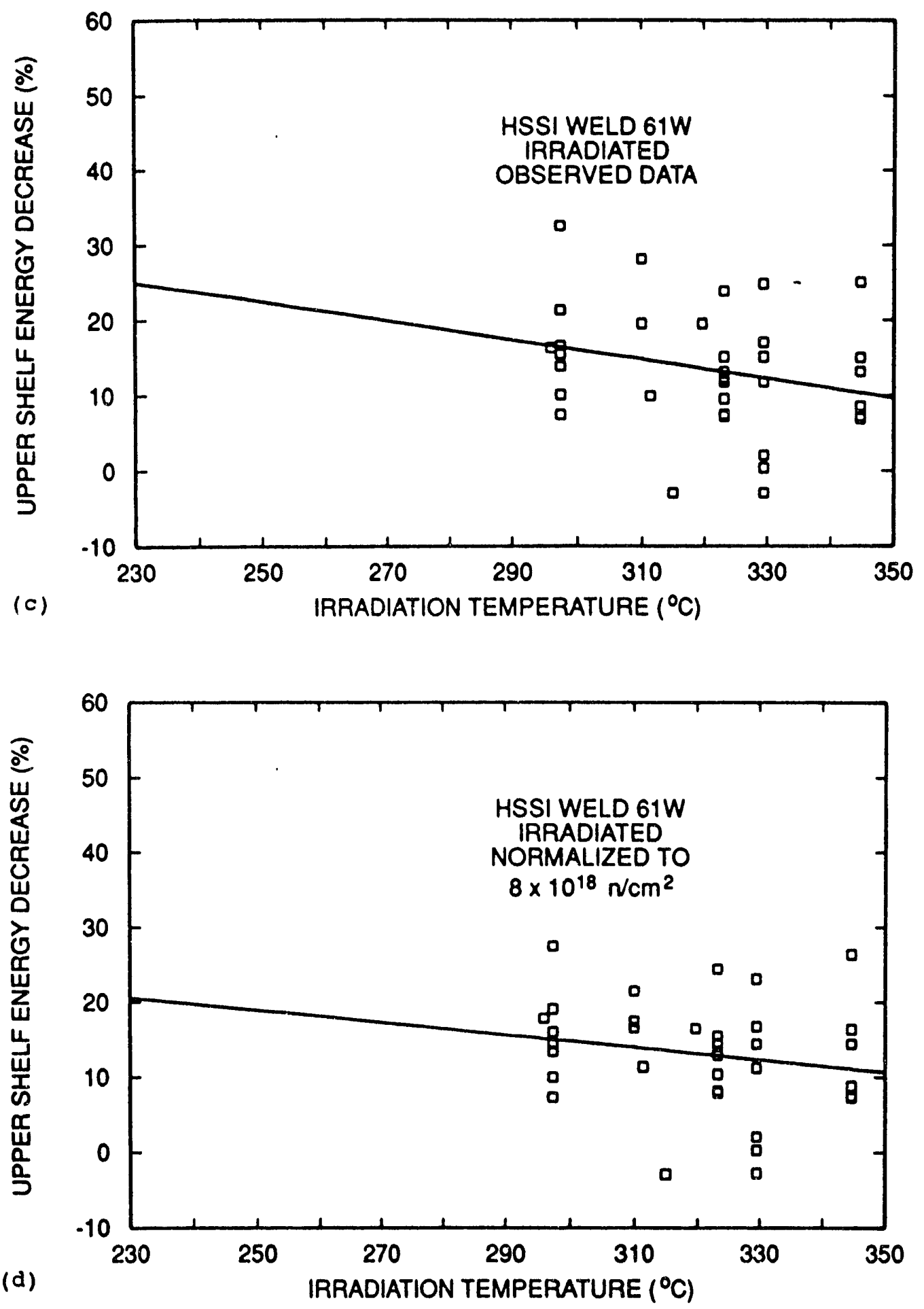

FIG. 6--(continued) 
analysis to be meaningful. Thus, Iinear fits have been used to relate the observed transition temperature increase, $\Delta T T$, and the upper-shelf energy decrease, $\triangle U S E$, to irradiation temperature according to

and

$$
\begin{aligned}
& \Delta T T=A_{1}+B_{1} T_{1}{ }^{\circ} \mathrm{C}, \\
& \Delta U S E=A_{2}+B_{2} T, J .
\end{aligned}
$$

The normalized trangition temperature increase results for $65 \mathrm{~W}$, $66 \mathrm{~W}$, and $67 \mathrm{~W}$ show an average standard error value on $B_{1}$ of close to one, whereas those for 6. W through $64 \mathrm{~W}$ are much less, indicating a more favorable data set for performing estimations. Using the regression results for $61 \mathrm{~W}$ through $64 \mathrm{~W}$ gives average dependencies on irradiation temperature of $-0.413^{\circ} \mathrm{C} /{ }^{\circ} \mathrm{C}$ for transition temperature and $-0.058 \mathrm{~J} /{ }^{\circ} \mathrm{C}$ for upper-shelf energy change. Interestingly, using the observed changes results in average dependencies of $-0.415^{\circ} \mathrm{C} /{ }^{\circ} \mathrm{C}$ and $-0.066 \mathrm{~J} /{ }^{\circ} \mathrm{C}$. Tables 7 and 8 summarize the results of transition temperature increase and upper-shelf energy decrease estimates, respectively. These tables provide the mean fluence, fluence standard deviation, and number of observations in the population for each weld, as well as the estimated changes at an irradiation temperature of $288^{\circ} \mathrm{C}$ for both the observed and normalized data. Finally, the 41-J temperatures and upper-shelf energies (at $200^{\circ} \mathrm{C}$ ) estimated for an irradiation temperature of $288^{\circ} \mathrm{C}$ are provided and compared to the estimates from Regulatory Guide 1.99 (Rev. 2) [19].

Using the linear fits, the transition temperature increases range from 57 to $108^{\circ} \mathrm{C}\left(103\right.$ to $\left.194^{\circ} \mathrm{F}\right)$ for the observed results and from 59 to $123^{\circ} \mathrm{C}\left(106-221^{\circ} \mathrm{F}\right)$ for the normalized results. Normalization resulted in substantial changes to the estimates for welds $64 \mathrm{~W}$ through $67 \mathrm{~W}$. The mean fluences for those four welds are much further removed from the normalization fluence than are those for $61 \mathrm{~W}$ through $63 \mathrm{~W}$. Regarding the upper-shelf changes, the decreases range from 16.2 to 26.28 for the observed results and from 15.7 to 37.08 for the normalized results. As with the transition region data, the fluences for $64 \mathrm{~W}$ through $67 \mathrm{~W}$ were relatively low and normalization resulted in substantial increases in the estimates. It is interesting to compare the estimates derived from these analyses with predictions based on Regulatory Guide 1.99

(Rev. 2) [19] without the "margin" specified in the Regulatory Guide. Tables 7 and 8 give those predictions and show that, for the observed transition temperature increases, the Regulatory Guide 1.99 predictions exceed the observed results in every case except for $63 \mathrm{~W}$ where the difference is only $2^{\circ} \mathrm{C}$. For the normalized case (i.e., for a fluence of $8 \times 10^{18}$ neutrons $\left(\mathrm{cm}^{2}\right)$, the Regulatory Guide 1.99 predictions exceed the test results in every case except for $63 \mathrm{~W}$ and $64 \mathrm{~W}$. For the upper-shelf energy decreases (percent decrease), the Regulatory Guide 1.99 predictions exceed the weld results in every case except for $65 \mathrm{~W}$. Most of the measured upper-shelf energy decreases for the welds were much less than the Regulatory Guide 1.99 predictions. The 41-J temperature given for each irradiated weld was calculated by adding the estimated transition temperature increase of the normalized data to the 41-J temperature for the unirradiated results. The results indicate that, for an irradiation temperature of $288^{\circ} \mathrm{C}$ and a neutron fluence of $8 \times 10^{18}$ neutrons $/ \mathrm{cm}^{2}(>1 \mathrm{MeV})$, the welds in this program would have $41-\mathrm{J}$ temperatures from 46 to $130^{\circ} \mathrm{C}\left(115-266^{\circ} \mathrm{F}\right.$ ) and upper-shelf energies (at $\left.200^{\circ} \mathrm{C}\right)$ from 58 to $79 \mathrm{~J}(43-58 \mathrm{ft}-1 \mathrm{~b})$.

\section{Charpy and Tensile correlations and Comparisong}

Various comparisons of CVN test results were examined for potential use as correlations. Regarding the effects of irradiation temperature on yield strength, Odette and Lucas [20] reported an average change of $-1.8 \mathrm{MPa} /{ }^{\circ} \mathrm{C}$ for high-copper alloys irradiated at high fluxes. As presented earlier, the tensile results for the low upper-shelf welds 


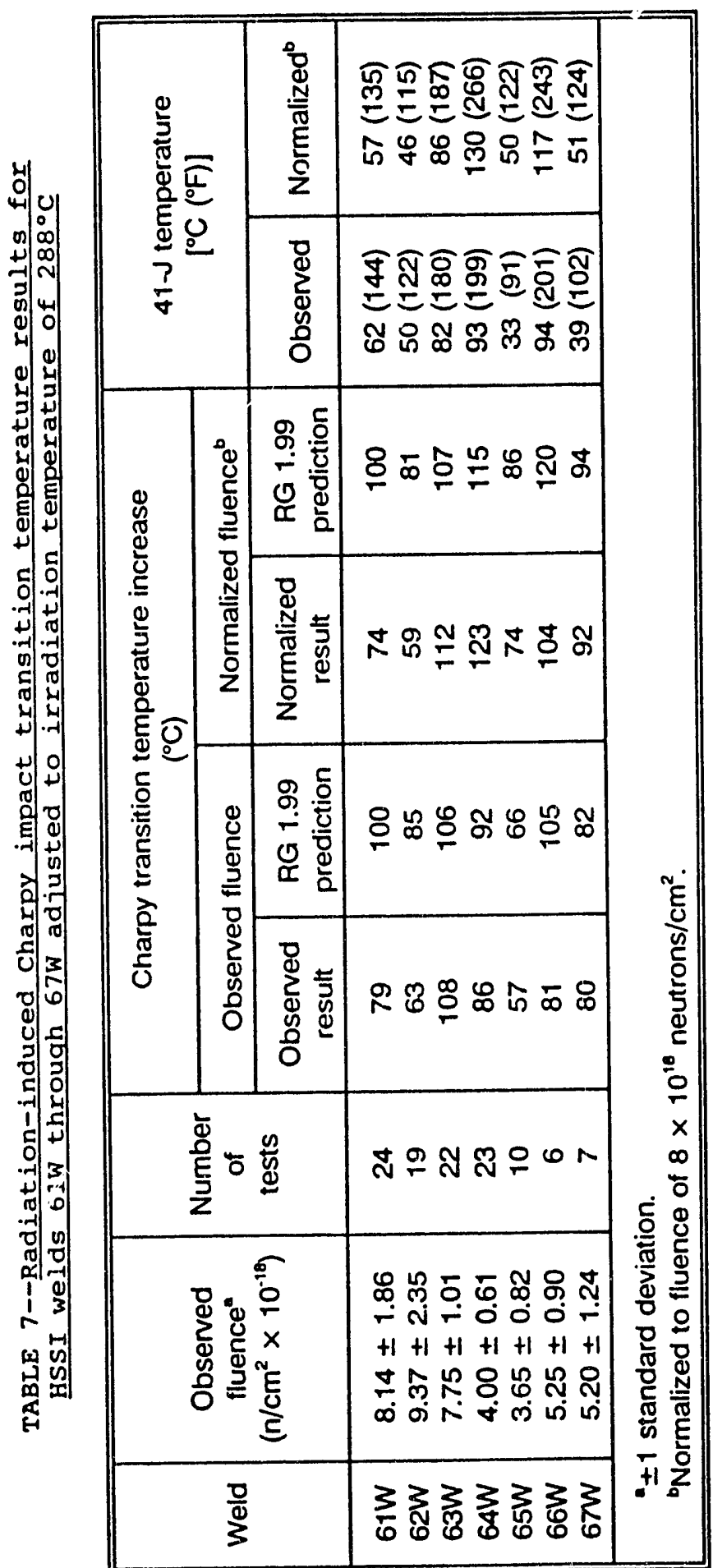




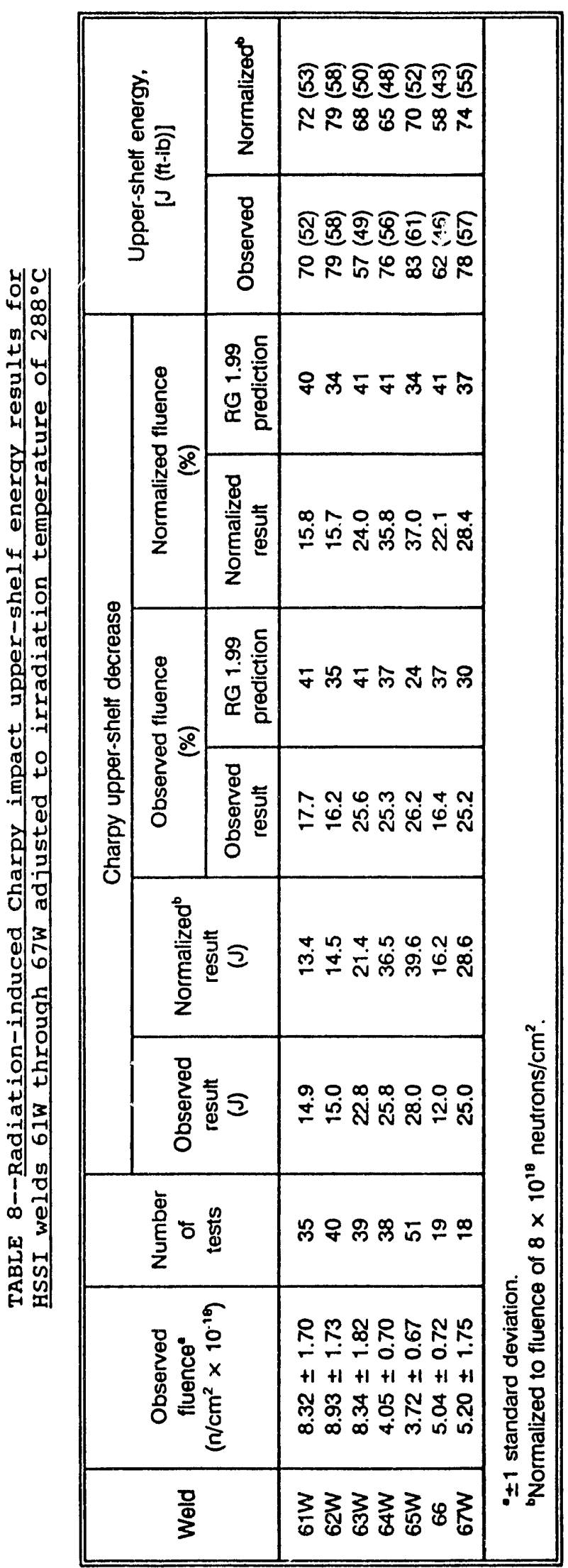


In this study exhibited an average dependence of yield strength on Irradiation temperature of $-1.15 \mathrm{MPa} /{ }^{\circ} \mathrm{C}$, in reasonably good agreement with the average results of ref. 20 considering the wide variations discussed in their paper.

In ref. 20, Odette and Lucas provide an extensive discussion of the hardening ( $i . e .$, increase in yield strength) dependence on neutron fluence. The power law dependencies are quite varlabie depending on flux, composition, fluence, material form, and irradiation temperature. Although they conclude that an exponent of about 0.5 is a good overall average, they presented data that indicated exponents varying from less than 0.1 to greater tran 1. As mentioned earlier, the data in this study were relatively sparse but a power law fit to the yield strength results gave an exponent of about 0.07 , quite low compared to the average results in ref. 20 even considering the reported scatter. It is noted, however, that the fluence range for the welds in this study was relatively small, less than one order of magnitude.

Regarding correlations between Charpy impact and tensile data, Odette, Lombrozo, and Wullaert (21) reported an average relationship between Charpy $41-J$ shift and yield strength increase as

$$
\Delta \mathrm{TT}_{41}=\mathrm{C} *\left(\Delta \sigma_{\mathrm{y}}\right)
$$

where the parameter $\mathrm{C}$ is about $0.65^{\circ} \mathrm{C} / \mathrm{MPa}$ for welds. For welds $61 \mathrm{~W}$ through $67 \mathrm{~W}$ irradiated at $288^{\circ} \mathrm{C}$ to a fluence of $8 \times 10^{18}$ neutrong $/ \mathrm{cm}^{2}$, the average value of $\mathrm{C}$ is $0.70 \mathrm{MPa} /{ }^{\circ} \mathrm{C}$ (the individual values ranging from 0.454 to 0.937 ), in excellent agreement with those of ref. 21 .

As discussed earlier, the Charpy impact data obtained at the measured fluences were normalized to a fluence of $8 \times 10^{18}$ neutrons $/ \mathrm{cm}^{2}$ using an exponential dependence on fluence of 0.5 . That value is reported by odette and Lucas (18) to be an average result for high flux irradiations in test reactors. It is interesting to note that they report an exponent of 0.18 for welds irradiated in surveillance capsules to intermediate fluences. In the same reference, they report an approximate sensitivity to bulk copper concentration such that

$$
\Delta \mathrm{TT}_{41} \approx \mathrm{C}(\mathrm{Cu}-0.1)^{0.5},
$$

where $\mathrm{C}=200 \pm 25^{\circ} \mathrm{C}$. A similar analysis of welds $61 \mathrm{~W}$ through $67 \mathrm{~W}$ gives

$$
\Delta \mathrm{TT}_{41}=234 *(\mathrm{Cu}-0.01)^{0.57} \text {, }
$$

in reasonably good agreement with those of ref. 18 .

Regarding the dependence of Charpy impact transition temperature shift on irradiation temperature, odette and Lucas (18) report changes from -0.4 to $-2{ }^{\circ} \mathrm{C} /{ }^{\circ} \mathrm{C}$ with the majority around $-1 \pm 0.2^{\circ} \mathrm{C} /{ }^{\circ} \mathrm{C}$. Those results are averaged for all materials over the irradiation temperature range from 250 to $310^{\circ} \mathrm{C}$. For the low upper-shelf welds of this study, a similar range of values was foind. However, only welds $61 \mathrm{~W}$ through $64 \mathrm{~W}$ experienced sufficiently wide ranges of irradiation temperatures for adequate analysis. The average dependence on irradiation temperature for those four welds was determined to be $-0.413 \pm 0.21^{\circ} \mathrm{C} /{ }^{\circ} \mathrm{C}$ ( \pm 1 standard deviation). Lowe (22) performed an analysis for welds $61 \mathrm{~W}$ through $63 \mathrm{~W}$ and determined a dependence of $-0.668 \pm 0.141^{\circ} \mathrm{C} /{ }^{\circ} \mathrm{C}$ (his result was reported as ${ }^{\circ} \mathrm{F} /{ }^{\circ} \mathrm{F}$ ). Using only $61 \mathrm{~W}$ through $63 \mathrm{~W}$ in this study yields a dependence of $-0.535 \pm 0.043^{\circ} \mathrm{C} /{ }^{\circ} \mathrm{C}$, closer to the value reported by Lowe. In this atudy, the dependence of upper-shelf energy on irradiation temperature was determined to be $-0.058 \mathrm{~J} /{ }^{\circ} \mathrm{C}$. Lowe's analysis [22] showed a change of about $-0.23 \mathrm{~J} /{ }^{\circ} \mathrm{C}$ (he reported $\left.-0.094 \mathrm{ft}-1 \mathrm{~b} /{ }^{\circ} \mathrm{F}\right)$. That value is quite different from that determined in this analysis and inspection of the unirradiated upper-shelf energies 
used by Lowe show them to be substantially higher than those used in the present study. That undoubtedly reflects the fact that he used all the reported unirradiated charpy test results as opposed to thls study, which used nnly the lower tending results from the hot cell charpy impact machine.

Berggren and stallman (23) performed nonlinear regression analyses of the Charpy data for $61 \mathrm{~W}$ through $67 \mathrm{~W}$ and developed model equations dependent on fluence, irradiacion temperature, and copper content. Transition temperature and upper-shelf enery reglons were fitted separately and linear expressions describing the energy vo test temperature relationship in both the transition and upper-shelf regions for unirradiated results were fitted to the data. For both the transition and upper-shelf regions, the temperature differences between the irradiated data and the linear fit of unirradiated data were entered into the fitting program. The authors note that the models must be applied wi.h caution outside the ranges of the variables within which they were developed.

Heller and Lowe (24) developed models for Linde 80 submerged-arc welds as part of a large study on low upper-shelf welds by $B \& W$. The equation they developed for Charpy shift includes fluence, $\mathrm{Cu}$, and $\mathrm{Ni}$, while that for upper-shelf energy change includes fluence, $\mathrm{Gi}, \mathrm{Ni}, \mathrm{Mo}$, and $\mathrm{Cr}$.

Tables 9 and 10 provide a comparison between the predictions using the models from Berggren and Stallman (23) and those of Heller and Lowe [24] with the results obtained in this study. All the values shown are based on an irradiation temperature and a fluence of $8 \times 10^{18}$ neutrons $/ \mathrm{cm}^{2}(>1 \mathrm{MeV})$. Table 9 shows that, for the transition temperature shift, the model predictions compare fairly well for the seven welds. The mean shifts predicted by the models are less than the results from this study for $63 \mathrm{~W}, 64 \mathrm{~W}$, and $07 \mathrm{~W}$. For the Heller and Lowe model, the upper tolerance bound would exceed the current results by a large margin. Regarding the upper-shelf energy, Table 10 shows that the Berggren and Staliman model overpredicts the drop for all we?ds except S5W. The model predictions from Heller and Lowe are mixed, with underpredictions in four cases and overpredictions in three cases. The upper tolerance bound from the latter model would encompass all the results. The two models do not compare very well for the upper-shelf case, probably as a result of the different values used for some of the unirradiated upper-shelf energies. More details concerning these models are presented in ref. 5 .

\section{COMPARISON OF TEST REACTOR AND SURVEILLANCE PROGRAMS RESULTS}

Comparison of these test reactor irradiation results with those from commercial power reactor surveillance programs is not generally possible because the correspondence between the HSST welds and the $B \& W$ weld designations is not presently available. Lowe (22) presented analyses of the data from the Second and Third Irradiation Series and compared the results with several power reactor surveillance program results with the same welds, $63 \mathrm{~W}, 65 \mathrm{~W}, 66 \mathrm{~W}$, and $67 \mathrm{~W}$. That report listed the surveillance program specimen irradiation temperature as $304^{\circ} \mathrm{C}$. A later paper [25] gives the irradiation temperature as $293^{\circ} \mathrm{C}$ for those same results.

To compare surveillance results with the results from this study, the surveillance results provided by Lowe (22) were adjusted to an effective irradiation temperature of $288^{\circ} \mathrm{C}$ and an effective fluence of $8 \times 10^{18}$ neutrons $/ \mathrm{cm}^{2}$. Table 11 shows the surveillance results before and after adjustment. Since the irradiation temperature was given as $293^{\circ} \mathrm{C}$, and using the previously determined temperature dependence of 
TABLE 9--Model predict lons of Charpy trangition temperature shift compared with results for irradiations at $288^{\circ} \mathrm{C}$ to $8 \times 10^{18}$ neutrons $/ \mathrm{cm}^{2}$

\begin{tabular}{|c|c|c|c|c|c|c|c|}
\hline \multirow{2}{*}{ Weld } & \multicolumn{3}{|c|}{$\begin{array}{l}\text { Content } \\
\text { (wt \%) }\end{array}$} & \multicolumn{4}{|c|}{$\begin{array}{l}\text { Transition temperature shift } \\
\left({ }^{\circ} \mathrm{C}\right)\end{array}$} \\
\hline & $\mathrm{Cu}$ & $\mathrm{Ni}$ & $\mathbf{P}$ & Result & $S \cdot B^{b}$ & $H \cdot L^{c}$ & RG $1.99^{d}$ \\
\hline $61 W$ & 0.28 & 0.63 & 0.020 & 74 & 91 & 98 & 100 \\
\hline $62 W$ & 0.21 & 0.54 & 0.016 & 59 & 71 & 72 & 81 \\
\hline $63 W$ & 0.30 & 0.69 & 0.016 & 112 & 94 & 109 & 107 \\
\hline $64 \mathrm{~W}$ & 0.35 & 0.66 & 0.014 & 123 & 106 & 113 & 115 \\
\hline $65 W$ & 0.22 & 0.60 & 0.015 & 74 & 73 & 84 & 86 \\
\hline $66 \mathrm{~W}$ & 0.42 & 0.60 & 0.018 & 104 & 123 & 112 & 120 \\
\hline $67 \mathrm{~W}$ & 0.27 & 0.59 & 0.011 & 92 & 86 & 88 & 94 \\
\hline $\begin{array}{l}{ }^{\circ} \mathrm{Re} \\
{ }^{\mathrm{b}} \mathrm{Fr} \\
{ }^{\mathrm{C}} \mathrm{Fr} \\
{ }^{d} \mathrm{Fr}\end{array}$ & A. & ller & A. L. & ve, Jr. & 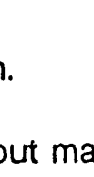 & & \\
\hline
\end{tabular}

TABLE 10--Model predictions of Charpy upper-shelf energy decrease compared with results for irradiations at $288^{\circ} \mathrm{C}$ to $8 \times 10^{18}$ neutrons $/ \mathrm{cm}^{2}$

\begin{tabular}{|c|c|c|c|c|c|c|c|}
\hline \multirow{2}{*}{ Weld } & \multicolumn{3}{|c|}{$\begin{array}{l}\text { Content } \\
\text { (wt \%) }\end{array}$} & \multicolumn{4}{|c|}{$\begin{array}{l}\text { Upper-shelf energy decrease } \\
\qquad(\%)\end{array}$} \\
\hline & $\mathrm{Cu}$ & $\mathrm{Ni}$ & $P$ & Result & S-B ${ }^{b}$ & $H \cdot L^{c}$ & RG $1.99^{d}$ \\
\hline $61 \mathrm{~W}$ & 0.28 & 0.63 & 0.020 & 16 & 39 & 25 & 40 \\
\hline $62 W$ & 0.21 & 0.54 & 0.016 & 16 & 32 & 27 & 34 \\
\hline $63 W$ & 0.30 & 0.69 & 0.016 & 24 & 39 & 19 & 41 \\
\hline $64 W$ & 0.35 & 0.66 & 0.014 & 36 & 35 & 23 & 41 \\
\hline $65 W$ & 0.22 & 0.60 & 0.015 & 37 & 29 & 21 & 34 \\
\hline $66 \mathrm{~W}$ & 0.42 & 0.60 & 0.018 & 22 & 51 & 29 & 41 \\
\hline $67 \mathrm{~W}$ & 0.27 & 0.59 & 0.011 & 28 & 44 & 23 & 37 \\
\hline & F. & $\begin{array}{l}\text { this } \\
\text { tallm } \\
\text { ller } \\
\text { ory } C\end{array}$ & and & $\begin{array}{l}\text { Berg } \\
\text { e, Jr. } \\
\text { ev. } 2 \text {, }\end{array}$ & t & & \\
\hline
\end{tabular}

about $-0.5^{\circ} \mathrm{C} /{ }^{\circ} \mathrm{C}$, the transition temperature shifts were decreased by $3^{\circ} \mathrm{C}$ (rounded from $2.5^{\circ} \mathrm{C}$ ). The temperature adjusted values were then normalized for fluence by using the fluence dependence term from Regulatory Guide 1.99 (Rev. 2) (19). This procedure was used because the Regulatory Guide 1.99 model is based on power reactor surveillance data; the power exponent is about 0.3 rather than the 0.5 value used in this study to adjust the test reactor data. The same procedure was followed for the charpy upper-shelf energy results except that the irradiation temperature adjustment was based on the previously determined dependence of $-0.058 \mathrm{~J} /{ }^{\circ} \mathrm{C}$. As the table shows, the results are mixed for both the transition temperature shifts and upper-shelf energy decreases. 
TABLE 11--Comparison of test reactor and power reactor irradiationg on charpy impact toughness for HSSI weldg

\begin{tabular}{|c|c|c|c|c|c|c|c|c|}
\hline \multirow{3}{*}{ Weld } & \multirow{2}{*}{\multicolumn{4}{|c|}{ Power reactor, observed results }} & \multicolumn{4}{|c|}{ Adjusted results } \\
\hline & & & & & \multicolumn{2}{|c|}{$\begin{array}{l}\Delta \pi \\
\left({ }^{\circ} \mathrm{C}\right)\end{array}$} & \multicolumn{2}{|c|}{$\begin{array}{c}\triangle U S E \\
(J)\end{array}$} \\
\hline & $\begin{array}{c}\text { Temperature } \\
\left({ }^{\circ} \mathrm{C}\right)\end{array}$ & $\begin{array}{c}\text { Fluence } \\
\left(\mathrm{n} / \mathrm{cm}^{2} \times 10^{19}\right)\end{array}$ & $\begin{array}{l}\Delta T \\
\left({ }^{\circ} \mathrm{C}\right)\end{array}$ & $\underset{(J)}{\Delta U S E}$ & $\begin{array}{l}\text { Power } \\
\text { reactor }\end{array}$ & $\begin{array}{c}\text { Test } \\
\text { reactor }\end{array}$ & $\begin{array}{l}\text { Power } \\
\text { reactor }\end{array}$ & $\begin{array}{c}\text { Test } \\
\text { reactor }\end{array}$ \\
\hline $63 W$ & 293 & 7.8 & 119 & 32.5 & 123 & 112 & 32.4 & 21.4 \\
\hline $65 \mathrm{~W}$ & 293 & 5.1 & 82 & 29.8 & 98 & 74 & 34.0 & 39.6 \\
\hline $66 \mathrm{~W}$ & 293 & 6.6 & 75 & 17.6 & 83 & 104 & 18.4 & 16.2 \\
\hline $67 \mathrm{~W}$ & 293 & 10.3 & 79 & 28.5 & 76 & 92 & 26.2 & 28.6 \\
\hline
\end{tabular}

Considering the variationg of irradiation temperature and fluence in the second and Third Irradiation Series experiments, as well as the uncertainties associated with the temperature histories of the surveillance specimens, it is difficult to evaluate the relationship between the test reactor and power reactor surveillance results. As the overall data base for surveiliance results increases, the developing view seems to be that a given material irradiated in a power reactor will experience somewhat greater eifects of irradiation than the same material irradiated in a test reactor at the same temperature and to the same fluence. In other words, there appears to be a flux effect such that irradiating at lower fluxes produces greater radiation damage $[20,21,26,27]$. However, that is a complicated phenomenon that may depend on fluence, neutron spectrum, material parameters, etc. The availability of data with which to make direct comparison is very sparse and, thus, comparisons between power reactor and test reactor effects will likely continue to be done from a statistical viewpoint.

\section{SUMMARY AND CONCLUSIONS}

The HSSI second and Third Irradiation Series had the primary objective of investigating the effects of irradiation on the ductile fracture toughness of seven commercially fabricated low upper-shelf submerged-arc welds. All the welds were fabricated with copper-coated weld wire and Iinde 80 flux that produced welds having relatively low Charpy upper-shelf energies in the unirradiated condition and relatively high sensitivity to neutron radiation.

Irradiation of the compact specimens at a nominal temperature of $288^{\circ} \mathrm{C}$ to an average fluence of about $8 \times 10^{18}$ neutrons $/ \mathrm{cm}^{2}$ (>1 MeV) was relatively successful. However, the charpy impact and tensile specimens were located at positions in the capsule where temperature control was less effective and the irradiation temperatures spanned the range 235 to $345^{\circ} \mathrm{C}$ for those specimens. Additionally, the neutron fluences varied from about 4 to $13 \times 10^{13}$ neutrons $/ \mathrm{cm}^{2}$ ( $\left.>1 \mathrm{MeV}\right)$. Although not desirable within the intended context of the experiments, those variations did provide the opportunity to investigate the effects of irradiation temperature and fluence (over the ranges observed) on the tensile and charpy impact properties of these low upper-shelf welds. The data available for such analyses were limited from a statistical viewpoint, yet did allow for some reasonable observations that could be compared 
with results from other studies. For most of those comparisons, the Charpy and tensile results were normalized for fluence varlations to an average Eluence of $8 \times 10^{18}$.

It is clear from the results obtained that all the welds experienced oignificant radiation-induced Charpy impact transition temperature ohifts, from 59 to $123^{\circ} \mathrm{C}$, and upper-ghelf energy decreases, from 16 to 378. Likewise, the increases in yleld and ultimate tensile strengths as a consequence of irradiation were significant, 21 to 358 and 13 to 208 , respectively, at room temperature.

Analyses of the effects of irradiation temperature on tensile properties and Charpy impact data showed that, within the Irradiation temperature range experienced by these welds and for a constant fluence, the radiation-induced increase in yieid strength changes $-1.15 \mathrm{MPa} /{ }^{\circ} \mathrm{C}$, while the ultimate strength and total elongation change $-0.79 \mathrm{MPa} /{ }^{\circ} \mathrm{C}$ and $-0.0148 /{ }^{\circ} \mathrm{C}$, respectively. For the Charpy impact data, the effect of irradiation temperature on transition temperature shift is about $-0.5^{\circ} \mathrm{c} /{ }^{\circ} \mathrm{C}$, meaning that a $1^{\circ} \mathrm{C}$ increase in irradiation temperature will cause a $0.5^{\circ} \mathrm{C}$ decrease in the transition temperature shift. Likewise, tie effect on upper-shelf energy decrease is about $-0.05 \mathrm{~J} /{ }^{\circ} \mathrm{C}$, meaning that a $1^{\circ} \mathrm{C}$ increase in irradiation temperature will cause a $0.05-J$ decrease in the upper-shelf energy drop. A correlation for the seven welds shows that the radiation-induced increase in Charpy transition temperature in degrees Celsius is about 708 that of the yield strength increase in megapascals, i.e., $0.70^{\circ} \mathrm{C} / \mathrm{MPa}$. Only the yield strength data were analyzed for the dependence on fluence (over a range of less than a factor of 10) and showed a power law exponent of 0.07 , which is much lower than that reported for other materials.

A comparison of the charpy results from this otudy with those from commercial reactor surveillance programs with the same materials showed mixed results. Out of the four common materials for which results are available, the transition temperature shifts and ur.er-shelf energy decreases from the surveillance programs, with no adjustments for fluence or irradiation temperature, exceeded those from the test reactor irradiations. From the analyses conducted in this study using all the data for each weld adjusted to a common irradiation temperature and fluence, the surveillance results exceeded those from the test reactor in two cases and vice versa.

The important observations and conclusions that can be stated based on the charpy impact and tensile results from the HSSI second and Third Irradiation series are enumerated below.

1. Analyses of irradiated tensile data showed a dependence on irradiation temperature of $-1.15 \mathrm{MPa} /{ }^{\circ} \mathrm{C}$ for yield strength, $-0.79 \mathrm{MPa} /{ }^{\circ} \mathrm{C}$ sor ultimate strengt $h_{1}$ and $-0.0148 /{ }^{\circ} \mathrm{C}$ for total elongation.

2. Analyses of irradiated charpy data showed a dependence on irradiation temperature of about $-0.5^{\circ} \mathrm{C} /{ }^{\circ} \mathrm{C}$ for transition temperature shift and $-0.05^{\mathrm{J}} /{ }^{\circ} \mathrm{C}$ for upper-shelf energy drop.

3. The results indicated that the radiation-induced changes in yield strengths in megapascals and Charpy transition temperature shifts in degrees Celsius for the seven welds can be expressed as $\Delta T T_{A 1} \approx 0.70 \star \Delta \sigma_{y}$.

4. The Charpy results indicated a dependence on copper concentration that can be expressed as $\Delta \mathrm{TT}_{41}=234 *(\mathrm{Cu}-0.1)^{0.57}$, where $\Delta T_{41}$ is degrees Celsius and copper (Cu) is weight percent. 
5. Comparison of the Charpy results with data for the same materials irradiated in power reactor surveillance programs showed mixed results with the power reactor changes being greater in some cases and the test reactor changes greater in others.

\section{ACKNOWLEDGMENTS}

The authors would like to acknowledge the contributions of Domenic A. Canonico (now with ABB-Combustion Engineering) and G. D. Whitman (now retired) for guidance and leadership in formulating and initiating the program, Walter J. Stelzman (deceased) for assistance with irradiation capsule construction and operation, and $T$. N. Jones (now retired) for tensile and charpy testing and hot cell coordination. We also thank Wllllam R. Corwin, HSSI Program Manager, and Alfred Tabotad, former NRC Technical Monitor, for financial support. Finally, in preparation of the paper, we express our thanks to Julia L. Blshop for manuscript preparation, and John G. Merkle and Fahmy M. Haggag for technical review.

\section{REFERENCES}

(1) Title 10, Code of Federal Regulations, Parts 0 to 199, U.S. Government Printing office, Jaruary 1987.

R. E. Johnson, Ed., Resolution of the Task A-11 Reactor Vessel Materials Toughness Safety Issue, Volumes 1 and 2, NUREG-0744 (Rev. 1), U.S. Nuclear Regulatory Commission, October 1982.

P. C. Paris, H. Tada, A. Zahoor, and H. Ernst, "The Theory of Instability of the Tearing Mode of Elastic-Plastic Crack Growth," pp. 5-36 in Elastic-Plastic Fracture, ASTM STP 668, J. D. Landes, J. A. Begley, and G. A. Clarke, Eds., American Society for Testing and Materials, Philadelphia, 1979.

(4) J. G. Merkle, An Overview of the Low-Opper-Shelf Toughness Safety Margin Issue, NUREG/CR-5552 (ORNL/TM-11314), Martin Marietta Energy systems, Oak Ridge Natl. Lab., Oak Ridge, Tenn., August 1990.

(5) R. K. Nanstad and R. G. Berggren, Irradiation Effects on Charpy Impact and Tensile properties of Low opper-Shelf Welds, HSSI Series 2 and 3, NUREG/CR-5696 (ORNL/TM-11804), Martin Marietta Energy Systems, Oak Ridge Natl. Lab., Oak Ridge, Tenn., August 1991.

(6) R. K. Nanstad, "Summary of the Heavy-Section steel Technology Program Irradiation Series," pp. 319-53 in Proceedings of the U.S. Nuclear Regulatory Commission Sixteenth Water Reactor Safety Information Meeting, Gaithersburg, Maryland, october 24-27, 1988, NUREG/CP-0097, Vol. 2, Office of Nuclear Regulatory Research, Washington, D.C., March 1989.

(7) S. A. Legge, T. R. Mager, and P. C. Riccardella, "Fracture Toughness Characterization of Irradiated A 533, Grade B, Class 1 steel Using 4T Compact-Tension Specimens," pp. 25-35 in Heavysection steel Technology Program Semiann. Prog. Rep. for Period Ending August 31, 1972, ORNL-4855, Union Carbide Corp. Nuclear Div., Oak Ridge Natl. Lab., Oak Ridge, Tenn., April 1973.

(8) Babcock and Wilcox Co., Alliance, Ohio, and Lynchburg, Virginia, An Investigation of Mechanical Properties and Chemistry Within a Thick MnMoNi Submerged Arc Weldment, EPRI NP-373, Electric Power Research Institute, Palo Alto, Calif., February 1977. 
(9) A. L. Lowe, Jr, and R. R. Seeley, Description of Weld Materials Furnished for the Second and Third Irradiation Series, HeavySection Steel Technology Program, BAW-1478, Babcock and Wilcox Co., to be published.

[10] J. A. Willlams, The Irradiated Fracture Toughness of ASTM A533, Grade B. Class 1 Steel Measured with a Four-Inch-Thick Compact Tension Specimens, HEDL-TME 75-10, Hanford Engineering Development Laboratory, Richland, Washington, January 1975.

(11) F. W. Stallman and F. B. K. Kam, Neutron Spectral Characterization of the Second Nuclear Regulatory Commission Heavy Section Steel Technology 4T-CT Irradiation Experiment, NUREG/CR-0505 (ORNL/NUREG/TM-285), Union Carbide Corp. Nuclear Div., Oak Ridge Nat1. Lab., Oak Ridge, Tenn., December 1978.

(12) A. L. Hiser, F. J. Loss, and B. H. Menke, J-R Curve Characterization of Irradiated Low Opper Shelf Welds, NUREG/CR-3506, MEA-2028, U.S. Nuclear Regulatory Commission, Washington, D.C., April 1984.

(13) J. A. Williams, Tensile Properties of Irradiated and Onirradiated Welds of A 533 steel Plate and A 508 Forgings, NUREG/CR-1158, HEDL-TME 79-51, Hanford Engineering Development Lab., Richland, Washington, January 1980.

(14) J. J. McGowan, Tensile Properties of Irradiated Nuclear Grade Pressure Vessel Welds for the Third HSST Irradiation Series, NUREG/CR-4086 (ORNL/TM-9477), Martin Marietta Energy Systems, Oak Ridge Natl. Lab., Oak Ridge, Tenn., March 1985.

(15) "Standard Practice for Effects of High-Energy Neutron Radiation on the Mechanical Properties of Metallic Materials, E 706(IB)," E 184-79, in 1989 Annual Book of ASTM Standards, Vol. 12.02, American Soclety for Testing and Materials, Philadelphia.

(16) D. A. Canonico, W. J. Stelzman, R. G. Berggren, and R. K. Nanstad, nse of Instrumented Charpy Tests to Determine Onset of UpperShelf Energy," Welding Research Supplement, 85-8-91-8 (May 1981).

(17) R. K. Nanstad, Characterization of Four Prestressed Concrete Reactor Vessel Liner Steels, ORNL/TM-7480, Union Carbide Corp. Nuclear Div., Oak Ridge Nat1. Lab., Oak Ridge, Tenn., December 1980 .

[18] G. R. Odette and G. E. Lucas, "Irradiation Embrittlement of Reactor Pressure Vessel Steels: Mechanisms, Models, and Data Correlations," pp. 206-41 in Radiation Embrittlement of Nuclear Reactor Pressure Vessel Steels: An International Review (Second Volume), ASTM STP 909, L. E. Steele, Ed., American Society for Testing and Materials, Philadelphia, 1986.

(1.9) "Radiation Embrittlement of Reactor Vessel Materials," Regulatory Guide 1.99, Rev. 2, U.S. Nuclear Regulatory Commission, Washington, D.C., May 1988.

(20) G. R. Odette and G. E. Lucas, Irradiation Bmbrittlement of Light Water Reactor Pressure Vessel stee1s, EPRI NP-6114, Electric Power Research Institute, Palo Alto, January 1989. 
[21] G. R. Odette, P. M. Lombrozo, and R. A. Wullaert, "Relationship Between Irradiation Hardening and Embrittlement of Pressure Vessel steels," pp. 840-60 in Bffects of Radiation on Materials: Twelfth International symposium, ASTM S'P 870, F. A. Garner and J. S. Perrin, Eds., American Society for Testing and Mäterialo, Phlladelphia, 1985 .

[22] A. L. Lowe, Jr., "An Evaluation of Linde 80 Submerged-Arc Weld Metal Charpy Data Irradiated in the HSST Program," pp. 201-213 in Effects of Radiation of Materials: 14th International Symposium, ASTM STP 1046, Volume II, N. H. Packan, R. E. Stoller, and A. S. Kumar, Eds., American Society for Testing and Materials, Philadelphia, 1990.

(23) R. G. Berggren and F. W. Stallman, "Statistical Analysis of Pressure Vessel steel Embrittlement Data," Trans. Am. Nucl. Soc. 44, 225-27 (June 1983).

(24) A. S. Heller and A. L. Lowe, Jr., Correlations for Predicting the Bffects of Neutron Radiation on Linde 80 Submerged-Arc Welds, BAW-1803, Babcock and Wilcox Co., Lynchburg, Va., January 1984.

[25] A. I. Lowe, Jr., "Review of B\&W Reactor Vessel Irradiated Materials Data," pp. 15-1-15-20 in 15th MPA Seminar, University of stuttgart, Federal Republic of Germany, Oct. 5-6, 1989.

[26] J. F. Perrin, R. A. Wullaert, G. R. Odette, and P. M. Lombrozo, Physically Based Regression Correlations of Embrittlement Data From Reactor Pressure Vessel Surveillance Programs, EPRI NP-3319, Electric Power Research Institute, Palo Alto, January 1984.

[27] W. N. MCElroy, R. Gold, R. L. Simons, and J. H. Roberts, "Trend Curve Data Development and Testing," pp. 505-34 in Influence of Radiation on Material properties: 13 th International symposium, ASTM STP 956, F. A. Garner, C. H. Henager, Jr., and N. Igata, Eds., American Society for Testing and Materials, Philadelphia, 1987. 

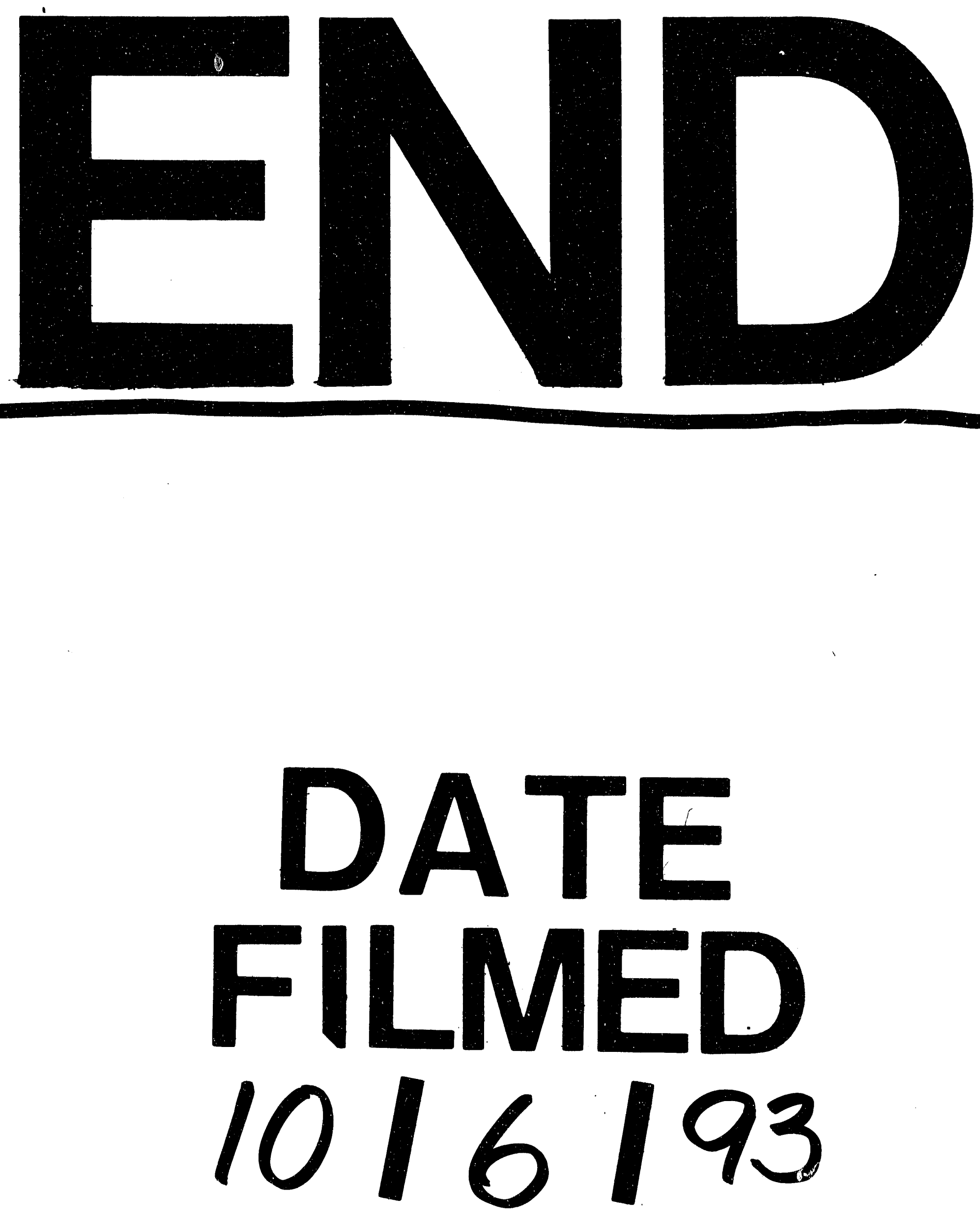

I 


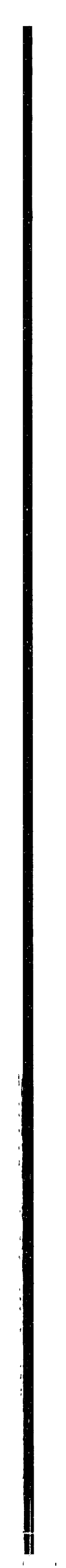

